\title{
Continuity Through Change: Navigating Temporalities Through Heirloom Rejuvenation
}

\author{
MELTEM TÜRE \\ GÜLIZ GER
}

\begin{abstract}
This study explores how heirlooms, usually regarded as objects of family identity and stability, can also become objects of evolving personal identities and change. Our approach is based on the role of materiality (as well as meanings) and multitemporality in heirloom consumption. The data generated through interviews, visual sources, and media documents reveal three rejuvenation processes that, given particular boundary conditions, renew heirlooms: uncovering, refreshing, and reconciliation. Our study also distinguishes three types of heirloom essence that can survive the heirloom's material and compositional transformations. Rejuvenation reintegrates the heirloom into the heir's life trajectory by imbuing it with a zeitgeist value and the heir's presence, helping the heir to better navigate her imaginaries of the past, present, and future. Beyond the ritualistic consumption or curation of heirlooms, our findings reveal a creative, playful, and proactive relation with heirlooms, evocative of craftwork. Moreover, the market, within particular boundaries, can help authenticate heirloom objects and facilitate their inalienability rather than necessarily destroying their authenticity. Our study has implications for the role of heirloom consumption in consumers' negotiations of continuity and change, the interaction of the symbolic and the material in heirlooms, and the inalienability-market relation.
\end{abstract}

Keywords: change and continuity, craft consumption, materiality, temporality, heirloom, inalienability, zeitgeist value

$\mathrm{C}$ onsumer researchers focus on heirloomsmaterializations of family meanings and traditions - as identity anchors: sources of rootedness and embodiments of family identity, which is a permanent part of the self (Baumeister 1987). Building on the premise that constant flux characterizes current social life and consumer identities are fluid (Bauman 2000; Giddens 1991), scholars have

Meltem Türe (meltem.ture@skema.edu) is an assistant professor of marketing, Skema Business School-Université Lille, Sophia Antipolis, 06902 France. Güliz Ger (ger@bilkent.edu.tr) is a professor of marketing, Bilkent University, Ankara, 06800 Turkey. The authors acknowledge and thank the editor, associate editor, and reviewers for the invaluable insights they provided.

Ann McGill and Eileen Fischer served as editors, and Søren Askegaard served as associate editor for this article.

Advance Access publication February 19, 2016 stressed the importance of heirlooms in providing consumers with a sense of stability and continuity (Bradford 2009; Chevalier 1999; Curasi, Arnould, and Price 2004; Curasi, Price, and Arnould 2004; Epp and Price 2010; Finch and Mason 2000; Price, Arnould, and Curasi 2000). Alternatively, we consider the iterative and interactive relation between change and continuity (Giddens 1990; Miles 2001; Schatzki 2002) and explore heirlooms' capacity for enacting change in addition to being sources of stability by focusing on the stories of change (of individual and family identities, society, practices, etc.) that might accompany the stories of continuity attached to heirlooms.

The literature highlights ritualistic and narrative aspects of consuming heirlooms and, in doing so, illuminates important domains such as curatorial consumption, guardianship, object attachment, and inalienability (Belk, Wallendorf, and Sherry 1989; Curasi et al. 2004; McCracken 1988; Price et al. 2000). However, existing 
studies cannot account for more transformative heirloom consumption practices such as wearing a restyled heirloom wedding dress or having one's heirlooms reformed and, in that process, seeking help from market agents as in TV shows like Something Borrowed, Something New. The proliferation of do-it-yourself (DIY) and retro fashions, media representations, and businesses may well set the stage for alternative interpretations of and interactions with heirloom objects. Driven by such observations in the market and in popular culture and the theoretical links between continuity and change, we focus on heirloom consumption practices that are more dynamic and transformative than previously found. We ask if, how, and when heirlooms are transformed.

Answering these questions provides important insights into consumers' relations with their heirlooms. If heirlooms objectify tradition and family (as opposed to modernity and the individual) and consumers turn to these objects to deal with the modern condition that "destroys tradition" (Beck, Giddens, and Lash 1994, 91), what do they do when modernity is as desirable as tradition is? If ideals of change, progress, and modernity prevail (especially, but not solely, in transitional societies [Sargin 2004]), studying heirloom transformation may reveal new ways through which consumers interpret modernity and tradition, and negotiate the past, the present, and the future.

To address our research questions and excavate diverse heirloom consumption practices, we conducted interviews and archived textual and visual documents. The research site, Turkey - an emergent economy facing rapid changes (Karadeniz and Ozdemir 2009)-serves our theoretical perspective of continuity and change. In Turkey, consumer identities are constituted through hybrid resources from the global modern as well as the traditional or the religious (Kandiyoti and Saktanber 2002; Sandıkçı and Ger 2010). With its rapidly changing socioeconomic and political scene, quest toward modernization and progress, and a simultaneous yearning for the nostalgic, this research site instantiates the broader global conditions of multiplicity, fluidity, and hybridity (Ger and Belk 1996; Nederveen Pieterse 1995). The context is fertile ground for a fresh unraveling of transformative heirloom consumption practices in addition to the well-known curatorial preservation.

In thinking through our diverse set of data, we draw from three theoretical perspectives. The first is the notion of heterogeneous uneven time (Bhabha 1994; Chatterjee 2001). In this view, practices that seemingly belong to different temporalities are constitutive elements of the present (Chakrabarty 2007) rather than solely remnants of a past long gone (Chatterjee 2001). Schau, Gilly, and Wolfinbarger (2009) adopt a similar approach in discussing how the elderly work relentlessly on their life narratives by using resources from the past, the present, and the future iteratively and nonlinearly in their consumption. Building on such studies and the notion of heterogeneous time, we propose that both heirlooms and their consumers live in "double time" (Bhabha 1994): in addition to being historical objects whose connections to an a priori past should repeatedly be signified, they are parts of a reproductive process as subjects of the present and future, which should also be signified and objectified. Such a view allows us to explore the continuous transformation of heirlooms' meanings and material content as the work of reflexive and ever-becoming consumers.

The heterogeneous view of time accords with the notion of becoming (Heidegger 1962; Schatzki 2002) as well as Giddens's (1990) argument concerning dynamism in social practices. Always on the verge of becoming, the contemporary reflexive consumer needs to continuously scrutinize traditions as they are passed from one generation to another to reinvent them and change their nature "in light of the incoming information" (Giddens 1990, 38). Thus we explore the interactive and iterative influence of the past, present, and future on heirlooms' reconstruction, transfer, and inalienability.

The literature acknowledges, if implicitly, the multitemporal nature of heirlooms. Over time, heirlooms' use can change as each generation uses them less in order to prevent damage (Curasi et al. 2004). As heirs reinvent and narrate their stories, heirlooms can become a part of the present (Stone 1988) and gain a projective power (Cieraad 2010). Heirlooms are also embedded in an ever-changing network of identities, objects, and spaces (Epp and Price 2010). Despite such hints at the dynamism of heirloom consumption, the literature usually operates by the logic of linear temporality, prioritizing heirlooms' relations to a nostalgic and idolized past to explain their inalienability and value (Curasi, Arnould, and Price 2004; Curasi et al. 2004; Finch and Mason 2000; McCracken 1988). Thus the literature has been silent on observed heirloom transformations such as the remodeled heirloom wedding dress.

Our second theoretical perspective is that of materiality, commonly used to explore consumers' relations with objects and the constitution of the social (Borgerson 2014; Epp and Price 2010; Latour 2005; Miller 1987). This notion draws attention to the material aspects of objects and to the process of objectification of relationships, identities, and values, rather than merely signification. Yet the literature regards heirlooms' materiality as a restrictive force: the form of the heirloom, whose alteration might endanger the meanings, traditions, and rituals attached to it, is to be protected (Curasi et al. 2004; Epp and Price 2010; McCracken 1988). In Epp and Price's (2010) study, for example, the family's desire to protect the heirloom table's size and form, for fear of losing its meaning, prevents its reincorporation into family life. The symbolic (e.g., meanings, indexical links) triumphs over the material, emphasizing its stability, and disempowers consumers who want to preserve the symbolic. However, if, as new materialists argue, "matter becomes" rather than "matter is" (Coole and 
Frost 2010, 10), heirloom objects cannot be excluded from such becoming. Hence this study follows a Latourian (2005) perspective of agency of the material to approach heirlooms not merely as objects of meanings but also as objects with materialities whose specific features and agency are as significant as the symbolic. Accordingly, we supplement the notion of the "continuous work of interpretation" (Beck et al. 1994, 64) with material work that heirs can undertake in their reflexive interactions with heirlooms to uncover and explain forms of transformative heirloom consumption.

Complementary to material work is craftwork, our third theoretical angle. Previous research on craft consumption, such as DIY, has found that craftwork positively contaminates ordinary objects with consumers' presence, imbuing them with love (Fuchs, Schreier, and van Osselaer 2015) and enhancing their value (Campbell 2005; Moisio, Arnould, and Gentry 2013; Sennett 2008). Heirlooms, however, are meaning-laden objects valued for their authentic links to the family. Threats to their authenticity can complicate heirlooms' transformation and limit the types of craftwork that can be employed. Likewise, if craftwork infuses the renewed heirlooms with the heirs' presence, it can muddle the status of these objects as embodiments of family identity versus the heir's. At the same time, by allowing for the metamorphosis of objects and practices while protecting their originality (Sennett 2008) and by legitimizing authenticity claims (Campbell 2005; Moisio et al. 2013), craft can potentially alter heirlooms without damaging their authenticity. Thus, within limits, craft can be central to heirloom transformation processes.

Our findings extend the literature in three ways. First, in addition to being anchors of continuity (Chevalier 1999; Csikszentmihalyi and Rocherberg-Halton 1981; Curasi, Arnould, and Price 2004; Curasi et al. 2004), heirlooms emerge as vessels of change, accompanying and helping consumers in their endless becoming through their own perpetual rejuvenations. Change-an heir's becoming-is accommodated, experienced, and negotiated as consumers transform heirlooms to uncover, refresh, or reconcile with them. The rejuvenated heirlooms become parts of new assemblies that revive, activate, and make them timelycompatible with the here and now and with consumers' life trajectories. Second, compared to a curatorial form of consumption (McCracken 1988), our findings reveal a more playful, proactive, and craft-oriented heirloom consumption style. If heirlooms face a tension between the present and the past, reflecting the dilemma of being in a family and being an individual (Dechaux 2002; Favart-Jardon 2002), rejuvenation empowers consumers to interact more creatively with their heirlooms. By altering these objects without damaging their perceived authenticity and power of summoning the past, consumers can heed the past while becoming in the present. Third, despite the commodification threat it creates for heirloom objects
(Bradford 2009; Curasi et al. 2004; McCracken 1988; Weiner 1992), the marketplace can also help enhance inalienability. It can endorse authenticity and timeliness concurrently. Its imageries and tools unleash appropriate ways of being playful with heirlooms and of rejuvenations that maintain inalienability.

We review and problematize the heirloom consumption literature. Then we describe the research context and methods and present the findings. We end with a discussion of the theoretical implications of the findings and directions for future research.

\section{CONSUMPTION OF HEIRLOOMS}

Heirlooms, with their indexical associations (Grayson and Shulman 2000) to familial past and identity, are inalienable objects that move across generations and provide individuals with a sense of stability, continuity, and connectedness (Belk 1990; Chevalier 1999; Curasi, Arnould, and Price 2004; Curasi et al. 2004; Finch and Mason 2000; McCracken 1988; Tobin 1996; Weiner 1992). Some studies have suggested that these traditional markers of the family are consumed less (Belk et al. 1989; McCracken 1988) by contemporary consumers who actively work on their individual identities (Baumeister 1987). Others, however, have found that consumers, who now lack fixed identity associations (Baumeister 1987; Nisbet 1973), yearn for heirlooms to "restore a sense of community and tradition" (Arnould and Price 2000, 141). This study bridges the two views and shows how consumers, as they make their own homes and families, accommodate their own individuality in their interactions with heirlooms.

Consumer researchers have explored how objects become heirlooms and how heirlooms stay inalienable (Curasi, Arnould, and Price 2004; Curasi et al. 2004; McCracken 1988; Price et al. 2000). As conceptualized by Weiner (1992), inalienability refers to an heirloom's ability to embody an individual's lineage and move through time while referring to one's original ancestral roots. Cherished objects can gain this status when consumers, pursuing symbolic immortality, attach them to specific rituals and transfer them to appropriate heirs (Curasi et al. 2004; Marcoux 2001; Price et al. 2000). Commodities can become heirlooms when associated with ancestral spaces for a long time (Chevalier 1999; McCracken 1988).

Two heirloom consumption practices protect inalienability: storytelling and ritualistic use/display (Curasi, Arnould, and Price 2004; McCracken 1988; Price et al. 2000). Stories enhance an heirloom's sentimental and identity value (Cieraad 2010) by mystifying its origins, embedding it in family history, and carrying its meanings across generations (Hurdley 2006). Through ritual use and display, heirlooms come into contact with the family during special occasions. Failure to comply with these rituals 
might destroy the heirloom's pre-given meanings, denying consumers the desired stability and hence continuity (McCracken 1988). To prevent this, guardians follow in their ancestors' footsteps in caring for heirlooms (Bradford 2009; Curasi 2006; Curasi, Arnould, and Price 2004; Curasi et al. 2004; McCracken 1988). The curators (McCracken 1988) carefully nurture heirlooms as a familial duty by displaying, grooming (Lastovicka and Sirianni 2011), and transferring them to eligible heirs. Otherwise, heirlooms turn invisible, forgotten, or inactive; their meanings are fossilized (Chevalier 1999), and they face the danger of alienation. Such accounts neglect the possibility of heirlooms adopting new life trajectories. Moreover, they foster a linear temporality in which the past, the main source of heirlooms' power and inalienability, is to be upheld, preserved, and transferred.

The literature relegates an ambiguous role to the present and the future. On one hand, the work of current and future heirs can enhance heirlooms' inalienability. New generations can (re)construct an heirloom's myths and stories, adding layers of meanings to it (Arnould and Epp 2006; Belk 1992; Dechaux 2002; Epp and Price 2008; FavartJardon 2002; Kramer 2011; Mason 2008; Stone 1988). Moreover, changes in household networks can reinstate a forgotten heirloom at the center of family practices (Epp and Price 2010). On the other hand, the present, indicative of change, can endanger heirlooms by decreasing their nostalgic value (Tuan 1980) or compatibility with the current household (Epp and Price 2010), and can create potential for physical damage. Similarly, the contemporary profane marketplace, with its emphasis on commodity value, can pose a threat to inalienability (Bradford 2009; Curasi et al. 2004; Weiner 1992). Seeking to sort out such ambiguity, we explore the more iterative interplay among the past, the present, and the future that can facilitate heirloom rejuvenation.

Another point of departure here is the role of the heir (vs. the predecessor) and the heir's relation to temporality. The literature focuses more on the ancestral past than the heir's personal present and nuclear family: elders transfer heirlooms and heirs are to maintain ancestral ties (Curasi et al. 2004; Finch and Mason 2000). In such a scenario, heirs have two choices: accepting or rejecting heirlooms. Consumers who welcome the past or regard heirlooms as compatible with their identities accept heirlooms by using and displaying them in predefined ancestral ways (Chevalier 1999; Cieraad 2010; McCracken 1988). Conversely, when heirs perceive the past as incongruous and burdensome or feel that the heirlooms do not match their current life, they reject and alienate them (Arnould and Epp 2006; Bradford 2009; Cieraad 2010; Curasi et al. 2004; Marcoux 2001). Such a dual (desirable vs. undesirable) vision of the past offers scholars much to explore as heirlooms can embody bimodal (i.e., both positive and negative) imaginaries of the past. Hence there may be a third way to relate to heirlooms: transforming heirloom objects to negotiate their potentially disagreeable links to the past.

Heirlooms' transformability has remained off the radar of consumer researchers, who have found even small alterations like repairs to be dangerous to heirlooms' authenticity (Harnish 1993/1994) and instead focused on heirlooms' material and symbolic preservation across time. Creative work on heirlooms has been studied in terms of heirs' reconstruction of heirlooms' narratives, leaving the material dimension underexplored. Epp and Price's (2010) study implies that heirlooms might be open to change as they move within household networks and are relocated to various spaces in the home. Despite such mobility, the domain of the symbolic reigns: an heirloom's spatial relocation is bound by its existing meanings and physical form. In contrast, our study integrates materiality and craft consumption perspectives to explore how heirlooms are transformed-materially as well as narratively, and with input from the marketplace-while still maintaining their heirloom status.

\section{THE SITE AND ITS IMAGINARIES}

The Turkish context in which heirlooms are embedded is one where the ideals of progress and development are deep seated. The country has undergone tremendous changes as waves of modernization movements struck the nation for over a century, constructing the Ottoman past as troublesome and regressive (Kasaba 1997; Keyman 2007), particularly for the urban collective consciousness (Bozdoğan and Kasaba 1997; Kozan 1994). The nation's pursuit of modernity and çağdaşlaşma (contemporarization) escalated after the mid-1980s as the state's neoliberal policies supported economic liberalism (Özman and Coşar 2007). Along with marketization, urbanization accelerated, increasing the urban population from 32\% in 1970 to $72 \%$ in 2012. Urbanization added a spatial dimension to the undesirable connotations of the past through their relegation to the rural ways of life. Aside from insufficient schools, health care, and sewer systems, village life has been associated with a lack of stylish furniture and consumer goods and the absence of the material culture of the modern.

The urban-rural and new-old constructions resonate with Williams's (1973) exposé of the British literary imagery: the country conjures up the imagery of the past (i.e., the old and natural ways, peace, and innocence, but also of backwardness, ignorance, and limitation) and the city of the future (i.e., modernization and progress). The significance of the Turkish urban-rural divide accords with Eickelman's (1998) finding that the urban-rural hierarchy dominates socioeconomic categories in the Middle East and Central Asia. Moreover, with urbanization, rural immigrants living in makeshift houses and providing unskilled labor now constitute $50 \%$ of the population in major 
Turkish cities. Such geographic proximity and the visibility of the rural in the city have ramifications in the intensified attempts of urbanites to distance themselves from the rural (Öncü 1997). The new-old and the urban-rural tensions are pronounced forces that govern Turkish everyday life and thus permeate the consumption of heirlooms. The pursuit of the modern, the desire for an altered state, can even become a quest for a permanent metamorphosis (Belk, Ger, and Askegaard 2003). Yearning for new objects constructs the old ones, sometimes even heirlooms, as outdated and backward.

Despite the struggle to distance oneself from the rural past in favor of urban modernity, traditions, family, religion, and ethnic roots are still crucial elements of Turkish daily life (Keyman 2007; Robins 1996). For instance, the family, despite changing from extended to more nuclear (Aytaç 2007), remains an imperative force (Alesina and Giuliano 2010). The ever-popular state-funded contemporary craft and art courses (e.g., sewing, glass painting, jewelry design, and woodworking) not only help define intrafamily gender roles but also promote craftwork (especially female labor) as an important part of domestic life. Moreover, in line with global consumption trends that favor nostalgia, there is an increasing revaluation of history and the Ottoman imperial legacy (Robins 1996) as evidenced by the high sales of history books and mushrooming of movies and television shows depicting the Ottoman period. A famous one, Muhteşem Yüzyll (The Magnificent Century), has reached a large audience in Turkey and in the Balkans and Middle Eastern countries formerly ruled by the Ottomans. Such shows materialize imageries of the Ottoman past through clothes, accessories, jewelry, and furniture. For people seeking a return to roots (Ger and Belk 1996) or wishing to relive a victorious past, such items attain desirability. In addition to the local distant past, the more recent global past has also become fashionable: the market is swept up with global (original and reproduced) retro/vintage objects, symbolizing sophisticated taste. Hence various imaginaries of desirable pasts and their specific objects are celebrated among Turkish consumers in pursuit of a modern life. As such this is a context occupied with the tensions of the moderntraditional, urban-rural, and new-old, framing consumers' perceptions of and relations with their heirlooms. In the midst of such tensions, the past is also laden with negative (backward or out-of-date) connotations, instead of being only positive, that is, nostalgic (Hecht 2001) or romantic and pastoral (Chevalier 1999). Embedded in bimodal imaginaries of the past and the village, and in relation to various presents and futures, heirlooms are linked to change.

Consider textiles and dowry chests. Dowry is a marital custom that has survived while incorporating change. Traditionally, handmade textiles and carpets were placed in a hand-painted or carved chest that the bride took to her new home. Dowry chests were mostly filled with textiles, historically precious production and trade items (Karababa 2012), although contemporary dowries include a diverse set of items such as home appliances. Dowry preparation, purchase, display, and exchange have been important not only to manifest the bride's skills and contribution to marital life (Sandıkçı and Ilhan 2004), but also to link females across generations by passing along skills and valuable objects between mothers and daughters. We expect that, as much as the family-specific stories of origin and rituals, the macro history of the dowry in Turkey and the cultural narratives and imaginaries surrounding its preparation and consumption will influence the meaning of an heirloom, such as a dowry chest or embroidered item, to a Turkish heir and what she does with it.

Consider two other items that have had a long history: the divan and copper utensils. A divan is a large backless sofa, backed into a wall with big cushions to lean on and usually turns into a bed at night. Copper pots and plates are used to cook and serve food. Ottoman times witnessed the prevalence of divans and copper pots in both upper-class mansions and lower-class homes, in villages as well as cities. Modernization movements diffused European-style decoration in urban areas, pushing objects incompatible with this style such as divans or copper utensils to the periphery. Home decoration became a venue for Turkish consumers to practice modernity (Esenbel 2000) and distance themselves from village life, the low class. The once ubiquitous and classless objects such as divans (Artıkoğlu 2006) became vivid markers of class identity. Today, a typical Turkish consumer lives in the city, sits on sofas or chairs, cooks with modern metal pots, eats from china or plastic plates, and is bombarded with messages of the new and improved. Left behind in rural homes, divans and copper utensils in the city are now mostly confined either to a "corner of the Orient" (şark köşesi) in homes (ensembles of objects associated with Eastern styles and rural life, as in figure 1) or to Oriental-themed hotels, cafés, and restaurants in touristic areas (www.dekorcenneti.com/ev-dekor asyon-fikirleri-2/sark-kosesi-dekorasyonu.html). As the status of such objects has changed in the broader sociocultural scene, so have Turkish consumers' relations with their heirlooms.

\section{METHODOLOGY}

To explore heirlooms in their context, we collected a set of interview, observational, and archival data: 345 pages of single-spaced interview transcripts, 205 photos, a 67 minute video, 43 pages of field notes, and a 5.67 megabyte archive of Internet content. The first author conducted the interviews, observed homes and retailers, and scrutinized TV programs, decoration and craft magazines, and the Internet for germane content for three years. The first four 
FIGURE 1

A TYPICAL "CORNER OF THE ORIENT" (ŞARK KÖŞESI) IN URBAN HOMES

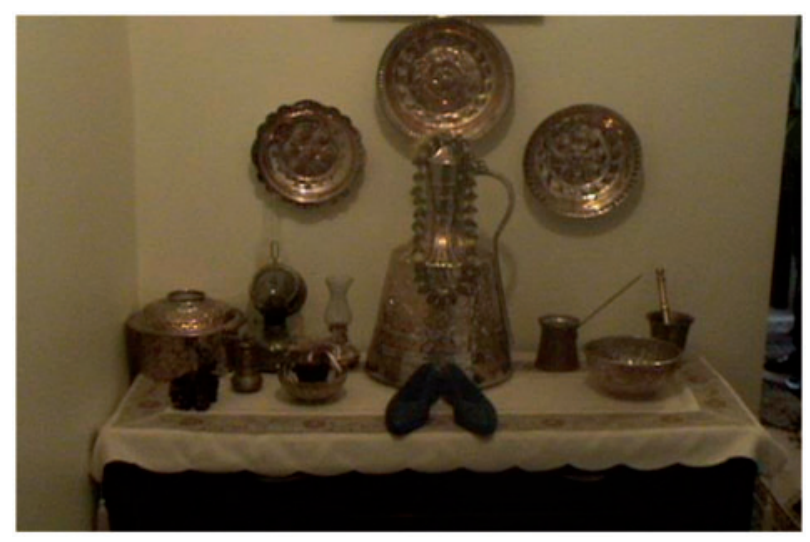

months entailed intensive fieldwork, followed up by intermittent data collection and analyses.

Following previous research, which found heirlooms to be important for the middle classes (Curasi et al. 2004; Price et al. 2000), we conducted in-depth interviews with 22 middle- and upper-middle-class urban Turkish consumers in Ankara. We recruited our first participants from among our acquaintances or their relations, who in turn put us in touch with other consumers with heirlooms. As the study progressed, we diversified our sample with respect to place of family origin (rural vs. urban) because initial analysis revealed this dimension to be of import with regard to heirloom consumption practices. When early analysis highlighted a previously unidentified practice-heirloom transformation-to be as common as preservation, the recruitment of new participants and the follow-up interviews focused on participants who had altered or planned to alter their heirlooms. This emergent sampling captured various stages of rejuvenation: some participants had a vague idea to alter their heirlooms, some had completed a rejuvenation plan, others had already transformed their heirlooms, and a few had even reversed the rejuvenation. Table 1 presents our sample of participants and their sample heirlooms.

Interviews were conducted in Turkish, took place at participants' homes or offices, and lasted for one and a half hours on average, with some going on for four hours. Follow-up interviews were conducted face to face or via email as new themes emerged and transcripts were reinterpreted: seven participants were interviewed twice and six participants three or more times. To understand the emic meanings and practices related to heirlooms, we first asked participants about the valued objects associated with their family roots and identity. Then we introduced the term aile yadigarl (Turkish for heirloom) to distinguish heirlooms from other special possessions mentioned. We inquired where each heirloom came from, the memories, stories, and future plans attached to it, and its current place in participants' lives. We asked participants, when they mentioned heirloom transformation, how they planned and undertook the rejuvenation and what they intended to do with the rejuvenated heirloom. When participants were hesitant about rejuvenation, we probed for the reasons, which revealed the boundary conditions. When participants did not mention rejuvenation, we asked how they felt about altering heirlooms and if they knew anyone with altered heirlooms. This inquiry expanded our sample by snowballing and encouraged participants to reflect on their own feelings through their observations of other people's heirloom rejuvenation.

Observations and visual data sources constituted another "basis for interpretation" (Arnold and Fischer 1994, 61), enhancing our exploration of the material and spatial aspects of heirloom consumption. We took field notes and photos or asked the participants to take photos of their heirlooms in their places at home. One participant provided us with a 67 minute video CD that had been previously recorded to document the family's heirlooms in a renovated ancestral home. This video revealed the creative ways consumers integrate heirlooms into their lives, how spatial and material ensembles (e.g., corner of the Orient) are used to alter heirlooms, and how the changing texture of the rural affects heirlooms. Because participants referred to the market when talking about their heirlooms, we observed and photographed retailers (e.g., home decoration, secondhand, and antique stores) to understand the market's role in rejuvenation.

We also perused the media seeking discussions, practices, and images of heirlooms that resonated with those of the participants. We had two main goals in choosing archival sources: contextualizing the participants' practices by understanding heirlooms' social life and public meanings in urban Turkey, and uncovering the role of the marketplace (the retail, decoration, and crafts worlds). For instance, the participants frequently declared being inspired by Derya Baykal, who has a television show, Derya Gibi, on domestic crafts and has written four volumes titled Yaratıcı Fikirler (Creative Ideas). We observed her shows, visited her website (deryabaykal.com), and read her books. Our documentary data sources also include online and printed media materials. We archived the online data into one online file for ease of access and iterative data analysis. The documents were collected from consumer blogs and forums with the most popular and frequent posts of consumer-to-consumer comments and advice about aile yadigarl, home decoration, consumption of old or retro objects, and DIY activities (eksisozluk.com, renklipudra.com, kadinlarkulubu.com, dekorasyoncini.com); retailer's web pages (dantell.com, mudo.com.tr, evmanya.com); two 
TABLE 1

PARTICIPANTS AND SAMPLE HEIRLOOMS

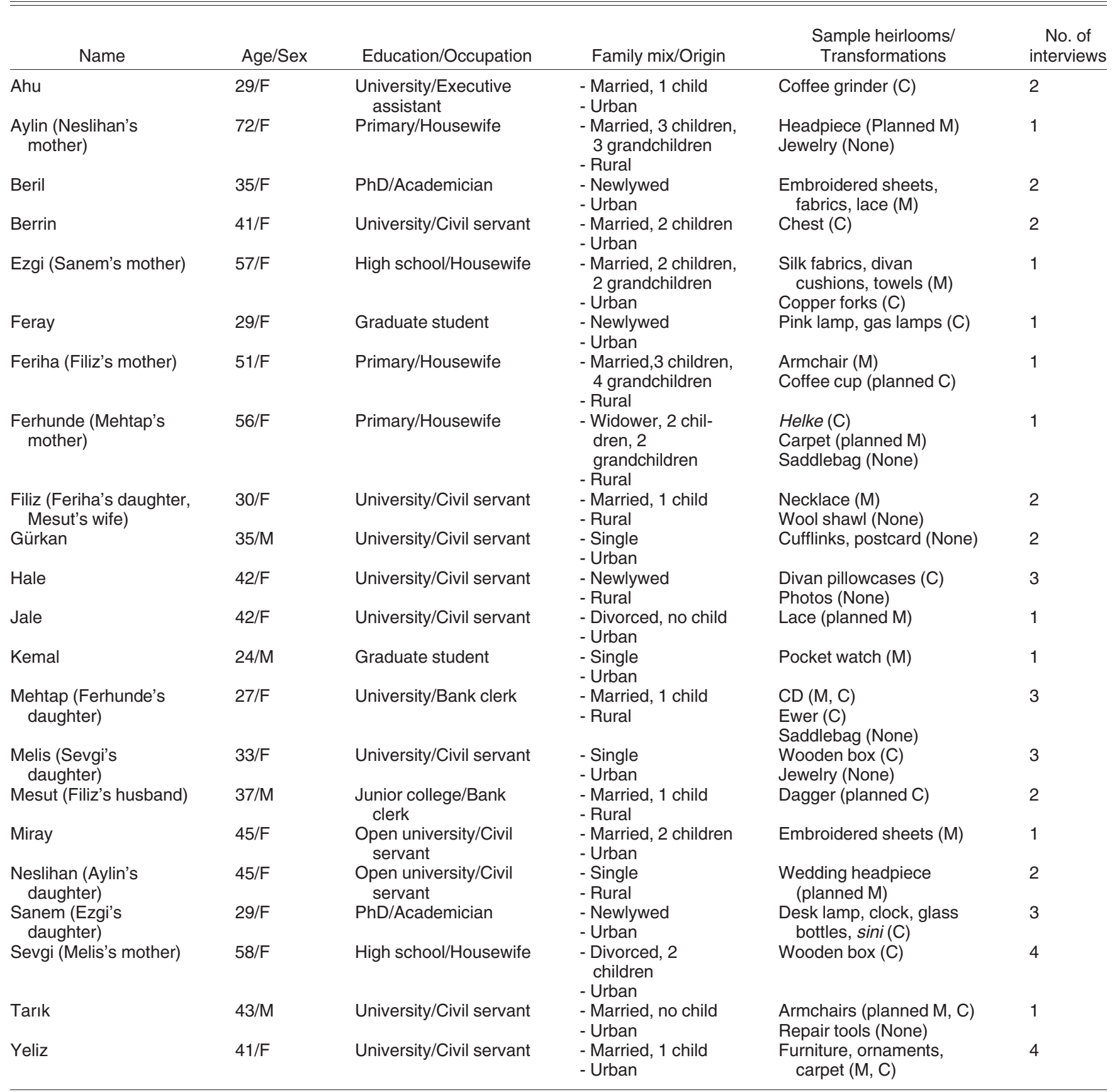

NOTE. $-\mathrm{C}=$ compositional transformation, $\mathrm{M}=$ material transformation.

online and printed urban home decoration magazines (evdose.com and Evim magazine, named frequently in the monitored blogs and cited in the articles); 51 articles on heirlooms, decoration styles, and craft or DIY from the two largest news agencies (Anadolu Ajansi and Ihlas Haber Ajansi) and in newspapers with the highest circulation rates (Sabah, Hürriyet, Milliyet, Zaman, and Posta); and two primetime national TV sitcoms (Papatyam and Çocuklar Duymasin) that depict the lives of a traditional extended family and a modern nuclear family, respectively.

We monitored these sources intensively for the first four months of the fieldwork until we reached saturation. The second round of documentary collection, less intensive and more intermittent, paralleled the process of interviewing 
and observing. These sources revealed popular decoration styles, aesthetics, and expert opinions as rooted in the cultural discourses that consumers refer to in creating their stories (Arnold and Fischer 1994; Thompson 1997).

Analysis and fieldwork overlapped considerably. Both researchers analyzed the data set first separately and then together by reading, coding, and constantly and iteratively comparing the data intratextually, intertextually, and with the literature. We used a hermeneutical approach and treated participants' narratives as parts of a socioculturally and historically constituted system of meanings and practices (Arnold and Fischer 1994, Thompson 1997). We analyzed interviews as narratives to explore heirlooms embedded in participants' life trajectories (Riessman 1993).

Once the initial analyses revealed transformation, we returned to the literature and reread the interviews and archival sources for potentially linked discourses. The discourses that enveloped depictions of heirlooms included, first, modernity and the new-old comparison ("modernization of the home," "getting rid of the weight of the past," "novelty"), which valorize the present and the future over the past and, second, urbanity, which valorizes the urban over the backward rural, both of which are to be expected from our account of the context. Two other pertinent discourses were the value of the distinguished authentic old and the advancement and praise of creative female craftwork, both of which, in turn, encouraged alterations of outdated objects including heirlooms. Comparing the archival data with the interviews revealed these tensions and discourses in the media and their reflections of heirloom consumption. Such interpretive iterations and reengagements with the theory deepened and challenged our understandings and continued until a meaningful story of how and why heirlooms underwent alterations emerged.

\section{REJUVENATION OF HEIRLOOMS}

Our findings revealed a set of creative heirloom consumption practices that the former studies did not address: rejuvenative transformation. Heirlooms embody and are embedded in a web of contradictory relations that consumers negotiate by way of rejuvenation. Rather than solely rejecting or preserving heirlooms through storytelling and ritual practices (Curasi et al. 2004; McCracken 1988; Price et al. 2000), heirs frequently consume them in a more transformative manner.

Heirlooms are rejuvenated through two types of transformation, both of which entail reassessing, repurposing, and reconfiguring their material and symbolic components. Because transformations can potentially destroy an heirloom's perceived integrity, their success is contingent on the interplay of the heirloom's essence and materiality, consumer competence, and market forces. We identify three rejuvenation processes through which consumers negotiate the tensions among their life trajectories, the heirloom's familial stories of origin, and its sociocultural connotations (figure 2).

Heirlooms are consumed in the nexus of "doings and sayings" (Schatzki 1996), pertaining, in our case, to heirs' homemaking and self-adornment practices. These practices, as shown in figure 2, are linked to the heir's own life trajectory and continuous identity work (e.g., as he or she gets married, divorced, loses cherished relatives, moves from the village to the city, or faces upward or downward social mobility). Moreover, as practices entail interactions among the triad of ideas/meanings, ways of doing/competences, and the material (Shove and Pantzar 2005; Shove et al. 2007), they are structured by dynamic sociohistorical discursive systems, what Arsel and Bean (2013) call "taste regimes." Figure 2 illustrates how homemaking and selfadornment practices are embedded in the previously mentioned four discourses: the tensions and dialogues between the desirable new and the burdensome old; those between the progressive urban and the backward rural; the taste for the authentic and distinctive old; and the craft ideals that promote domestic female handicraft. These discourses nurture a temporal aesthetic contemplation directed at heirlooms, regardless of the richness of their stories of origin or ancestral meanings. This scrutiny, in our context, is revealed as a "modernizing gaze" (Kandiyoti 1997) that creates concerns about the present and the future.

Such embeddedness creates tensions in two ways. First, an heirloom, whose "social history" (Appadurai 1986) links it to specific taste regimes, embodies both private family meanings (FM) and public sociocultural connotations (SCC), as illustrated in figure 2. The familial subtexts can be weak (WFM) or strong (SFM) and consist of ancestral and/or emergent private meanings. The heirloom also objectifies strong or weak public subtexts with negative or positive connotations (SN-SCC, SP-SCC, WN-SCC, and WP-SCC). An heirloom's private and public subtexts can cohere or conflict with each other. As incoherent elements disturb a unity (Canniford and Shankar 2013; Epp and Price 2010; Parmentier and Fischer 2015), conflicting SCC and FM create tensions in heirloom consumption. Second, heirlooms are open to the dynamism of taste regimes (Arsel and Bean 2013) that situates the interaction of competences, materials, and meanings - the practice triad. When some of these interacting components demand stability while others thrive for change (DeLanda 2006), tensions arise in the domain of homemaking and self-adorning practices, influencing the status of heirlooms. For instance, an heirloom chair (e.g., Yeliz's chairs) can disengage from its household network (Epp and Price 2010), despite its desirable SFM, when a change in broader aesthetic sensibilities reveals its specific form or upholstery now to be distasteful and unsuitable to the heir's home decor. Laden by the tensions between heirlooms' private (FM) and public (SCC) meanings and 
FIGURE 2

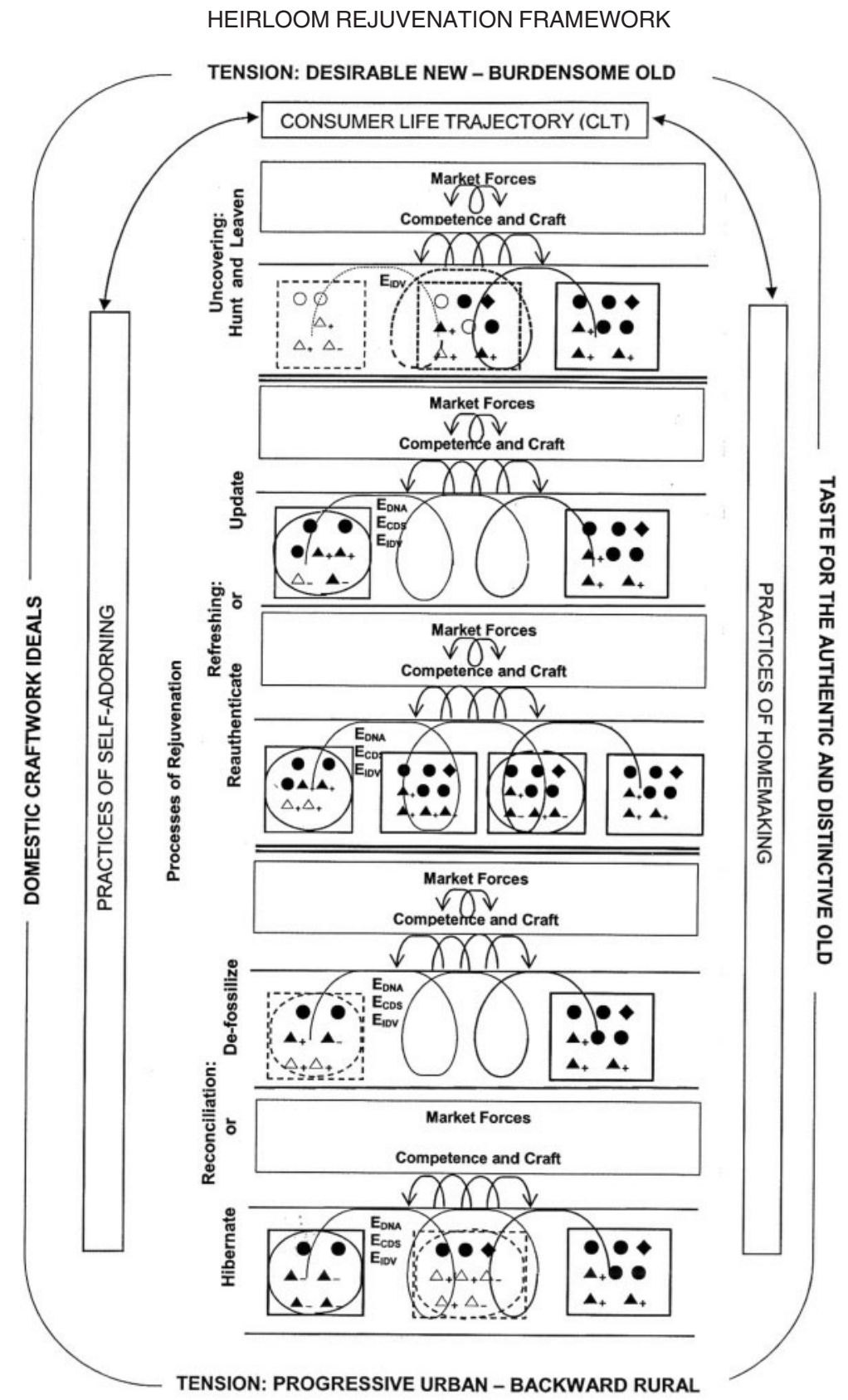

$\begin{aligned} & \text { KEY } \\ & \Delta_{-}: \text {Weak negative sociocultural connotations (WN-SCC) } \\ & \Delta_{+}: \text {Weak positive sociocultural connotations (WP-SCC) } \\ & \boldsymbol{\Delta}_{-}: \text {Strong negative sociocultural connotations (SN-SCC) } \\ & \boldsymbol{\Delta}_{+}: \text {Strong positive sociocultural connotations (SP-SCC) } \\ &-: \text { Strong family meanings (SFM) } \\ &: \text { Weak family meanings (WFM) } \\ & \mathrm{E}_{\mathrm{DNA}}: \text { Heirloom essence as DNA } \text { The heir's self-contamination (HSC) } \\ & \mathrm{E}_{\mathrm{CDS}}: \text { Condensable heirloom essence } \\ & \mathrm{E}_{\mathrm{IDV}}: \text { Indivisible heirloom essence }\end{aligned}$


among the contradictory calls for continuity and change within the practice triad, heirloom consumption can nurture the rejuvenating practices observed in this study.

Figure 2 illustrates the emergent heirloom rejuvenation processes that restore the coherence among the heirloom's meanings and materiality and the heir's evolving identity. Embedded in the heir's life trajectory and practices of homemaking and self-adorning, each rejuvenation process imbues the heirloom with the heir's self-presence (HSP in figure 2), giving it a zeitgeist value (time appropriateness) in addition to its lineage value. The transformed heirloom incorporates change and becomes congruent with the heir's present self.

\section{Forms of Heirloom Transformation}

We identify two forms of heirloom transformation (bottom right in the key for figure 2). Material transformation alters an heirloom's physical form and material (shown as circles becoming rectangles in figure 2) to enrich and renew its functions and aesthetic appeal. Compositional transformation repurposes heirlooms by integrating them into new and aesthetically superior material and spatial ensembles without altering their material form. We explain later what each transformation entails and how they alter heirlooms without harming their authenticity.

Material Transformation. Heirlooms, even those with SFM, can be materially altered to become timely and align with the heir's life. For Kemal $(24, \mathrm{M})$, his grandfather's pocket watch, despite its many stories to tell, had a traditional flair that "was not my style." To bring it into his present, Kemal enhanced its functionality by converting it into a wristwatch, discarding the "outdated" chain and adding a new strap to the watch. Also consider Filiz's necklace, which simultaneously embodied SFM, SP-SCC, and SNSCC:

The pearl necklace my mother-in-law gave me on my wedding. Her grandmother had bought it in Mecca. She had it redesigned to match my style.... It is very valuable for me, something that had all these memories...but also, she thought about me and what I would like. Originally, it was long. She used to wear it in two rows, classic. Before giving it to me, she went to jewelers, had it shortened ...put a gold pendant in the middle... more trendy ... like the ones in the shops. It feels modern.... I wear it happily on special days .... I will use it and keep it, then, pass it along. (Filiz, $30, \mathrm{~F})$

Filiz had already accepted the necklace out of respect for its strong ancestral stories and "all these memories" (SFM). Moreover, its associations to a holy place, Mecca, provided the necklace with desirable public meanings (SPSCC). Yet in its original form, the necklace concurrently objectified the outdated traditional (SN-SCC) that did not fit the image Filiz likes to convey. To enhance the coherence among these conflicting subtexts, Filiz's mother-inlaw used its flexible materiality (i.e., the separability of the beads) to have it shortened and reconfigured. The pendant from the profane market refreshed the necklace, symbolizing Filiz's addition to the family. By transforming the necklace to inscribe it with Filiz's tastes and individuality, rather than imposing it on her as it was, Filiz's mother-inlaw ensured that it remained active and powerful. The renewed necklace accommodates both ancestors and heirs: it embodies the past in its indexical links, the present, as a "trendy" necklace fit for Filiz, and the future, as it creates new memories with Filiz's family to be transferred to her children.

Material alterations can also save heirlooms from physical death. Embroidered by her grandmother and used by her mother, Beril's heirloom sheet was withering away. She and her mother decided to transform it for the newly married Beril:

The embroideries were beautiful. It was my grandmother's work. I see similar work at shops now, very expensive too .... But ours is original. It was worn and looked old. We thought they could be used as bed covers. My mom visited the linen stores and talked to the women there, looked for new designs. (Beril, 35, F)

Beril's gaze reveals the ancestral dowry embroideries as embodying not only the past but also the present in their originality compared to the commodities in stores. Despite these positive subtexts, the sheet's material decay endangered the heirloom. Acting on the sheet's malleability and bringing in her competence, Beril's mother combined it with new fabrics and trimming styles. She hired labor to extract the embroideries and sew them on the new material (figure 3). Employing craftsmanship, she knitted lace for the fringes of the bedcover and "beautified" the heirloom. Hence the sheet, customized for Beril's tastes, "did not stay in the past." Beril uses it for special occasions and hence it "will live longer" into the future.

Compositional Transformation. Consider Hale's ancestral pillowcases repurposed into rugs (figure 4). Made of handwoven carpet, dyed with madder (a historical root dye), and attached to a burlap posterior, the carpet cases have lineage value. They nevertheless carry SN-SCC due to their associations with rural divans:

The carpets are precious, otantik. Grandpa willed that we get them. They were used as pillowcases in the countryside, for divans. We don't have a divan or a corner of the Orient.... I emptied out the filling, put the carpet cases on the floor as rugs, in the TV room and the bedroom. They look beautiful now and match my home. (Hale, 42, F) 
FIGURE 3

BERIL'S EMBROIDERED SHEETS REJUVENATED INTO A BEDCOVER

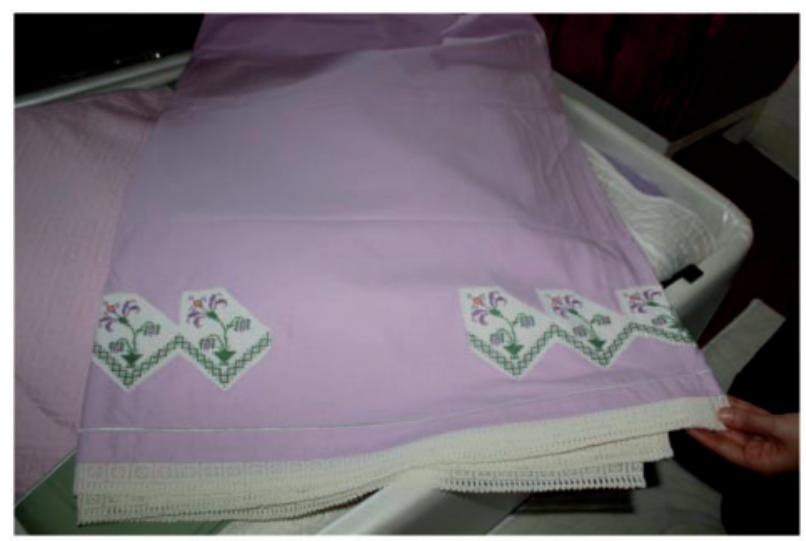

FIGURE 4

HALE'S PILLOWCASES AS RUGS ON THE FLOOR OF HER BEDROOM

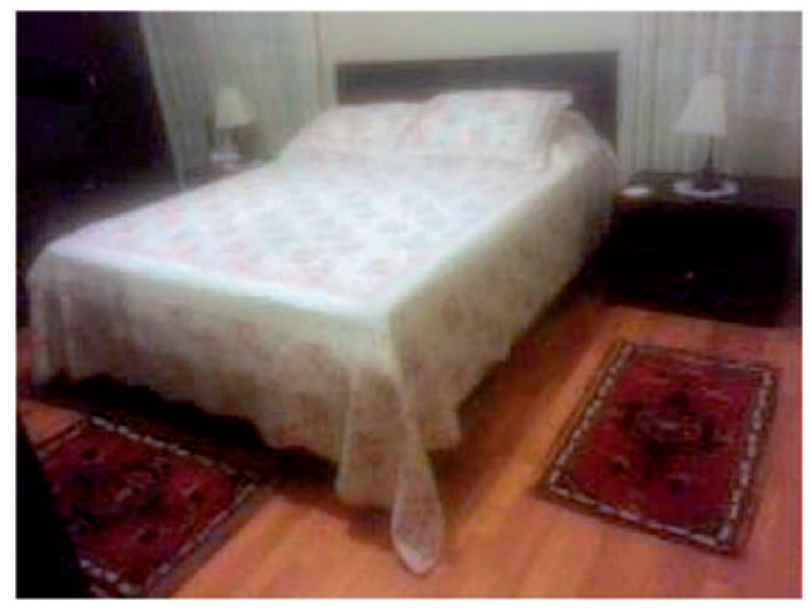

Hale's self-perception as a modern, progressive woman is reflected in her homemaking practices and love for "light, modern furniture." Her "precious" pillowcases are for and from the "countryside" as they are otantik: original in a rural sense as reproduced in the Oriental imageries created in the market. By removing their fillings without altering the otantik material and using them as rugs, Hale managed to distance her cases from the rural divan and situate them within the contemporary taste for the distinctively authentic. Repurposed to become attuned to Hale's current decoration and homemaking sensibilities, the inalienable rug cases move to the future with the possibility of readopting their original use:

They ... will always move along... always within the family .... I can give them to my nephews but never outside the family.... They [her nieces and nephews] can change it again afterwards...stuff them like pillows if they like. (Hale, 42, F)

While Hale's composition removed her heirloom pillowcases' rough rustic associations, Ahu's (F, 29) weakened her antique coffee grinder's subtexts, which were "too heavy" for her "casual, not classically decorated" home. Passed down through many generations with SFM, the grinder is valuable and a "huge responsibility." The coffee grinder's specific form and its 19th-century Ottoman palace seal legitimize it as antique, as authentically and distinctively old, while simultaneously indexing a onceimperial but long-gone past that conflicts with Ahu's Westernized life. To integrate it into her current life "without showing it off, like a nouveau riche," with no pretensions of royal ancestry, Ahu assembled it with her beloved books in the bookcase in her family room. While the literature argues that heirlooms are displayed in ways that highlight their singularity and hereditary associations (Chevalier 1999; McCracken 1988), Ahu composed a collage of temporalities to reduce the grinder's heaviness. Blended in with her books that reflect "my own accomplishments" and "can be passed down to people I like after my death," the coffee grinder now fits her present and can potentially live in the future.

Likewise, Sevgi (F, 58) rejuvenated her hand-carved wooden box, inlaid with mother-of-pearl, into an accessory box for her daughters. The box, previously used to offer cigarettes to guests at her parents' house, became idle after her mother died. Marrying into a less well-heeled family, Sevgi kept the posh box hidden. The box, with SP-SCC as the market reproduced its authentic form, resurfaced after Sevgi got divorced and redecorated her home with "special things" from her parents. Since the box's previous use conflicted with Sevgi's and her daughters' antismoking identities, they turned it into an accessory box for the vanity table in the teenagers' room after cleaning it so "it no longer smells." The box now has daily contact with Sevgi's family, who appreciate its FM as well as its new functionality and "authentically engraved form," which is valuably old in the marketplace.

The stories just recounted illustrate that being transformed, materially and/or compositionally, can be vital rather than damaging for heirlooms' inalienability and viability. Rejuvenated heirlooms, inscribed by stories of change, move across multiple temporalities iteratively. As opposed to the rare and ritualistic heirloom usage (Curasi et al. 2004; McCracken 1988; Price et al. 2000), transformed heirlooms obtain greater visibility and (even mundane) functionality in daily domestic life that, perhaps surprisingly, enhance inalienability. Rejuvenation serves inalienability by preventing the heirloom's material decay and by increasing its contact with present and future family members, allowing it to collect new FM. Moreover, 
TABLE 2

TYPES OF HEIRLOOM ESSENCE AND REJUVENATIONS

\begin{tabular}{|c|c|c|}
\hline Indivisible ( $\left.E_{I D V}\right)$ & $\begin{array}{l}\text { Essence inseparable from the heirloom's } \\
\text { whole form }\end{array}$ & 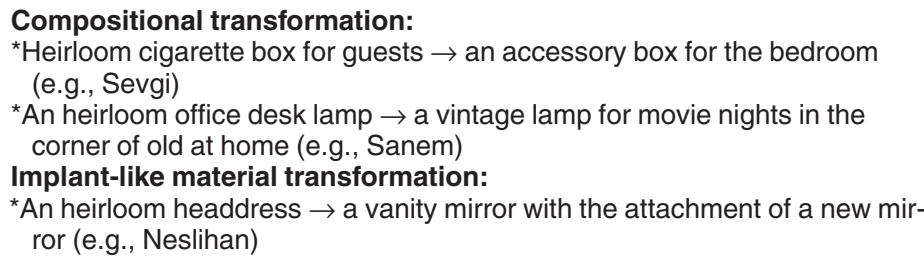 \\
\hline Condensable ( $\left.E_{\mathrm{CDS}}\right)$ & $\begin{array}{l}\text { Essence encapsulated in some parts of } \\
\text { the heirloom }\end{array}$ & $\begin{array}{l}\text { Material transformation (compositional is also possible): } \\
\text { *An heirloom pocket watch } \rightarrow \text { wristwatch with its chain cut and a strap } \\
\text { added (e.g., Kemal) } \\
\text { *Heirloom photos } \rightarrow \text { cut and reframed or imprinted on pillowcases } \\
\text { (e.g., Sevgi, Melis) } \\
\text { *Heirloom armchairs } \rightarrow \text { renewed upholstery with new fabrics } \\
\text { (e.g., Yeliz, Feriha) }\end{array}$ \\
\hline
\end{tabular}

alterations positively contaminate the heirloom with the heir, aligning it with the heir's current life and contemporary taste regimes, and providing it with a zeitgeist value in addition to its lineage value. That is, inalienability is retained not just by selecting and grooming heirs to preserve heirlooms (Curasi et al. 2004; McCracken 1988; Price et al. 2000), but also by properly transforming heirlooms to fit into the heirs' life trajectories. Whether a transformation succeeds or fails depends on three boundary conditions.

\section{Boundaries of Heirloom Rejuvenation}

In imagining and undertaking any rejuvenation, participants were, first and foremost, occupied with the essence of the heirloom. An heirloom's essence refers to the perceived authenticity that creates a feeling of rightness and lineage for the heirs (Belk et al. 1989; Collins, Glaebe, and Murphy 2011). This essence, in interplay with the heirloom's material form, is assessed in the context of the circulating public discourses. The essence-materiality nexus, in turn, interacts with the forces in the marketplace and the heir's competence. The destiny of a rejuvenation attempt is contingent on this interplay.

The rejuvenation process, even with radical changes to an heirloom's form or uses, can succeed if it keeps the perceived essence intact. Otherwise, it fails. Consider how Beril failed in converting her "magical heirloom fabric" into a purse by stitching it. The fabric had been gathering "magical" essence in her mother's dowry chest with other fabrics. She would secretly check the chest and "gaze at the treasures." The new mundane form disrupted this essence as Beril could "look at it whenever I want" and that it "felt too ordinary ... as if, by folding it, I had buried the emotions attached to it." The fabric's rejuvenation adventure ended as Beril undid the transformation and put the fabric back into the chest. However, not all heirloom transformations are so easily reversible.

We present three types of essence that guide rejuvenation. We then describe how heirs' competence can enhance or hinder their rejuvenation attempts. Finally, we discuss the ways the market contributes to rejuvenation as it influences the perceived essence-materiality relation and competence.

Types of Heirloom Essence. Essence can be indivisible, DNA-like, or condensable (table 2 provides definitions and examples of rejuvenation styles).

Indivisible essence $\left(\mathrm{E}_{\mathrm{IDV}}\right)$ is inseparable from heirlooms' material form, consistent with previous views (Belk 1992; Bradford 2009; Curasi et al. 2004; Epp and Price 2010; McCracken 1988; Price et al. 2000). Because removing or altering a part might disrupt the coherence of heirlooms with $\mathrm{E}_{\mathrm{IDV}}$, they are rejuvenated with their form intact either through compositional transformations or material alterations that are akin to body implants. While the $\mathrm{E}_{\mathrm{IDV}}$ of Ahu's heirloom coffee grinder steered its compositional change, the $\mathrm{E}_{\mathrm{IDV}}$ of Neslihan's ( $\left.\mathrm{F}, 45\right)$ grandmother's bridal headdress (figure 5) allows material alteration. Neslihan's silver cap's form, with its inflexible but delicate materiality, captures its essence. She plans to 


\section{FIGURE 5}

NESLIHAN'S SILVER WEDDING HEADPIECE

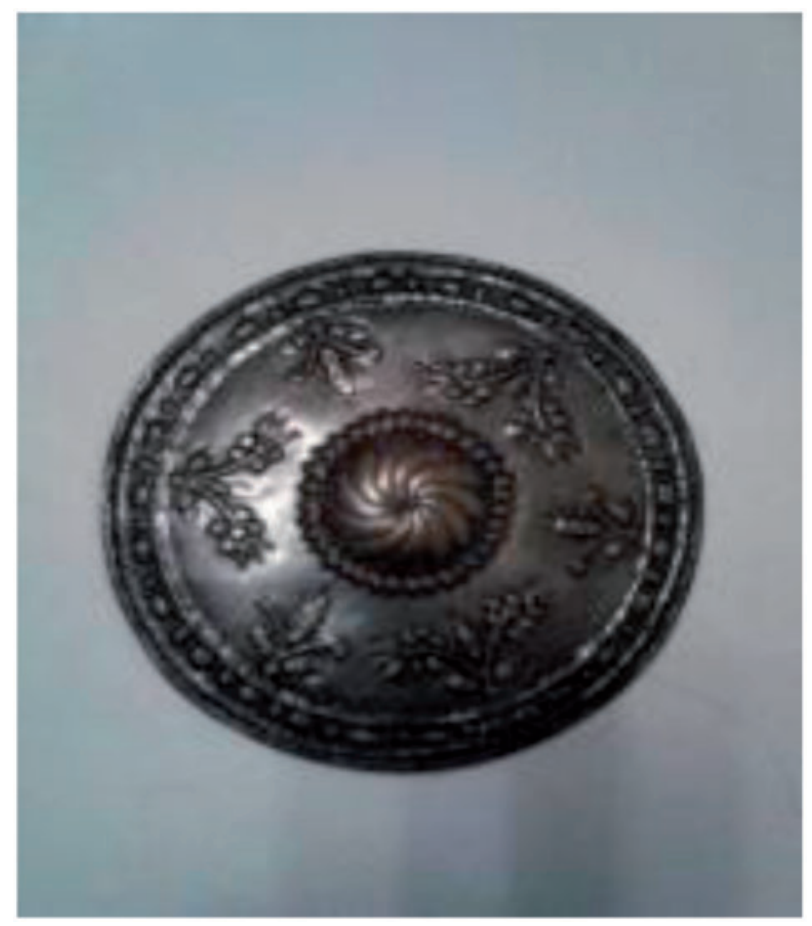

turn the headdress from bygone times into a hand mirror for her vanity table by installing a mirror on one side to modernize it while maintaining the essence on the other side.

Essence as DNA ( $\left.\mathrm{E}_{\mathrm{DNA}}\right)$ is homogeneously distributed through the heirloom's form. Every cell of the heirloom contains the essence, licensing the heir to disassemble or cut it in diverse ways, combine it with new pieces, and discard the idle pieces without spoiling its heirloom status, as long as some original parts are preserved. Recall the reduction and redesign of the pearl beads of Filiz's necklace. Likewise, Beril cut off a roll of lace knit by her grandmother and sewed the pieces on the handkerchiefs used at her henna night (a bachelorette party with relatives and friends). The handkerchiefs now rest in her own dowry chest.

Condensable essence $\left(\mathrm{E}_{\mathrm{CDS}}\right)$ can be encapsulated in some part of the heirloom such as the embroidery of a tablecloth or the black-and-whiteness of a photo. Heirlooms with $\mathrm{E}_{\mathrm{CDS}}$ are rejuvenated by preserving this significant part, the heart of the heirloom, while altering other parts; keeping the clock part, Kemal turned his grandfather's pocket watch into a wristwatch to "use it daily and remember my grandpa ... it will not waste away."

In summary, exploring the interplay of the material and the symbolic revealed three types of heirloom essence that can survive rejuvenation. Such essence is in contrast to the literature that regards heirlooms' perceived authenticity to be too fragile to survive any alterations (Curasi et al. 2004; Epp and Price 2010; McCracken 1988).

Consumer Competence and Craft. The heir's competence is vital for the perception of an heirloom's essencemateriality nexus, as well as for crafting appropriate transformations. Competence harbors bodily and cognitive skills including cultural capital (Bourdieu 1984) and experience, mechanical dexterity, and courage (Fromm 1997) to select, use, and combine tools and practices necessary to achieve a task (Watson and Shove 2008).

Competence helps, first, in developing a critical gaze directed at heirlooms-to assess the components and explore ways of reconfiguring them. Hale envisaged the potential of her authentic heirloom rug cases to be apt for modern urban sensibilities before she formed a material modification and a composition that realized this potential. Second, competency in areas such as composing, embroidering, or sewing brings out the heirs' craft skills, allowing them to invest their body and mind into the rejuvenation process. This self-investment leaves the heir's personal mark (Campbell 2005; Sennett 2008) on a renewed heirloom (heir's self-contamination [HSC] in figure 2). Inscribed by the heir's presence, the renewed heirloom withstands alterations while maintaining its authenticity for the family.

Lack of knowledge of specific taste regimes or skills in handcrafts prevents consumers from envisioning and applying any transformation. Gürkan $(35, \mathrm{M})$, who had "never seen anything like that around me," has doubts about altering his heirloom cufflinks, which he says would "spoil their originality." In addition to lacking interest or inspiration, or having "no idea about what to do," he lacks the handcraft skills necessary to convert the cufflinks into an ornament for himself.

Thus both imaginative and material capacities (Epp, Schau, and Price 2014) are crucial for successful rejuvenations. The marketplace can improve these capacities and hence enhance consumers' competence by inspiring and legitimizing the renewal of particular heirloom objects, improving craft skills, and providing resources for rejuvenation.

Market Forces. The marketplace, in interplay with consumer competence (figure 2), catalyzes heirloom rejuvenation. It encourages a desire to "claim the past... old objects that narrate a past," as Yeliz explains, and often inspires a pursuit of heirlooms. Many decoration websites, such as evdöşe ("furnish home" in Turkish), suggest enmeshing multiple temporalities in contemporary spaces:

\footnotetext{
When renovating your house, you do not need to buy new things. Old objects will allow you to work more freely when you practice your art.... The chest you inherited from your grandma becomes an indispensable part of your renovation projects. Time to get them out of the attics where they collect dust! (evdose.com, December 26, 2010)
} 
Other than promoting a taste for the authentic and distinctive old, the market portrays some objects (e.g., chests, gas lamps, lace) as being caught up in the new-old, urbanrural, or modern-traditional tensions, and it offers resolutions that can, in turn, inspire rejuvenation of heirlooms:

Lace, an essential legacy in Turkish culture, must be carried on to future generations.... Irresistible in every era, lace gains a different identity in Dantell collections. We use handmade Turkish lace on modern fabrics as well as Belgian, French, and Swedish lace in chic Dantell designs. We design lace with "haute couture" understanding ... and passion for combining tradition with modernity. (dantell.com, November 6, 2011)

Retailers like Dantell (dantel is Turkish for lace) legitimize lace as a legacy that lives across time and into the future, provided it changes and "gains a different identity." Dantell suggests that Turkish lace, with its traditional and rural connotations, becomes fitting for modern urban decoration when it is assembled with Western lace in a chic and classy manner. Dantell's work contributes to the modernizing gaze that creates urban-rural and new-old tensions for heirloom lace and hence enhances its rejuvenation.

Moreover, the market can enhance heirloom rejuvenation by improving consumers' competence in various ways, from perceiving heirlooms' essence-materiality nexus to applying specific craft skills. For instance, Derya Baykal has highlighted black-and-whiteness as a sign of authenticity, inspiring transformations of such heirloom photos. Her "eccentric methods," as some participants called them, have further guided some of the rejuvenation endeavors we observed. Another important market force that improves consumers' DIY and craft skills is the statefunded domestic handcraft courses mentioned earlier. The instructor in her handcraft course, for instance, helped Miray $(45, \mathrm{~F})$ to knit embroideries and lace on her heirloom fabric and turn it into kitchen curtains for her daughter. It is now a "nostalgic piece with double value." Likewise, popular news agencies promote specific craft methods for renewing and beautifying old objects such as gas lamps_-an heirloom object for some:

Gas lamps became important in decoration.... Try different methods to integrate your hidden treasures into your lives... The glass sections can be painted in any color and design. We can craft beautiful looks. (Anadolu Ajans1, November 20, 2010)

Other than using the market for inspiration or to rekindle their eye and enhance their competence, consumers also borrow market resources such as labor or goods to compensate for the skills they lack. Beril's mother, who felt that her sheet's delicate embroideries needed a professional touch, spent a lot of time and visited many stores to hire skillful workers. Filiz's necklace was reassembled by a trustworthy jeweler who had experience in handling jewelry.
Despite its positive influence, the market can pose a threat to heirlooms when there is no room for the heir's own stamp in the rejuvenation process, that is, the play of her own competence to contaminate the renewed heirloom. Despite their SFM, Jale postpones rejuvenating her mother's pieces of lace until she can contribute to the process:

I have always thought of making use of them but, I have to really imagine it... come up with a design to use them in another fashion. I never use lace, my home is modern. I want to do something I can use ... to reclaim them. I don't know what. (Jale, 42, F)

Interviewer: Aren't there TV shows and magazines for this?

Like Derya Baykal, right? She does some good stuff, to enhance value.... I need to invest time specifically on this. Put my mind to it and think about what to do. (Jale, 42, F)

Despite the ample marketplace imageries that can help Jale integrate the lace into her life, she wants to invest herself into her lace's rejuvenation and leave her own stamp on it.

As the market supplies consumers with ideas and inspiration, offers courses to develop handicraft skills and competence, and provides resources, it facilitates the craft-like aspects of heirloom rejuvenation. Like Epp and Velagaleti's (2014) parents who control the outsourced parenthood practices to establish their presence, heirs control and supervise the rejuvenation process by investing themselves in it (e.g., by planning, finding apt labor, and executing the craft). Self-investment imbues the renewed heirloom with the heir's stamp, protecting its authenticity and decreasing its perceived marketization even when the process is mostly outsourced.

Compared to curatorial practices that reproduce heirlooms' previous functions and stories (Curasi et al. 2004; McCracken 1988; Price et al. 2000), rejuvenation, despite being bounded by heirlooms' essence and materiality, consumers' competence, and market forces, provides more opportunity for heirs in what they make of their heirlooms. Consumers enact their control and creativity through three rejuvenation processes that concurrently boost their heirlooms' zeitgeist value and inalienability.

\section{Processes of Heirloom Rejuvenation}

The processes of uncovering, refreshing, and reconciling (figure 2) align the trajectories of consumers and their heirlooms. Specificities of each process emerge as heirs negotiate the tensions among their personal histories, current lives and aspirations, and the heirloom's stories of origin and SSC.

Uncovering. A two-stage rejuvenation process, shown in figure 2, helps heirs to activate their families' forgotten heirlooms. Unused and not looked at for a long time, these 
heirlooms have usually lost their specific stories of origin but embody vague connections to ancestors (WFM) and WP/WN-SCC. The first stage of the process resembles a treasure hunt in heterogeneous time: the heir gazes at the heirloom critically and creatively to identify its potential life (Parsons 2008; Thompson 1979). The second step, leavening, links the sought out heirloom to specific spaces and materials to strengthen and legitimize its new life.

Consider Sanem's desk lamp. Recently married into an affluent family, Sanem manifests her own taste by decorating her new home "using the old and the new together." This has led her back to her and her husband's roots, to their heirlooms, to bring back home:

Me and my husband, we read magazines, go to stores, flea markets.... I realized I liked retro and started looking around .... We wanted things from our families. I visit my late grandfather's house and search for what I can take.... I got his radio, which reminds me of my childhood, my grandpa. I also got the carpet from my great aunt's home.... All these objects fetch a large price in stores today. What I have are original and from the family, not replicas like they sell.... My husband's family had a desk lamp from his late grandfather's office. Unbelievably beautiful, he must have bought it at least 50 or 60 years ago. Big, with its body made of dark wood, like those in the vintage stores but more beautiful. We put it in the family room. (Sanem, 29, F)

The lamp lacked specific stories of origin and embodied WFM for its links to a beloved ancestor, the grandfather. The gestalt created by the materiality of the lamp indexing the specific era of its design such as its color and the wooden body enticed Sanem, a self-proclaimed retro enthusiast. The iconic images of vintage-retro style floating in the marketplace provided a treasure map for the hunt by improving Sanem's competence with regard to retro items and her assessment of the lamp and, consequently, revealing the lamp's $\mathrm{E}_{\mathrm{IDV}}$. Fueled by these market-mediated images, Sanem imagined a future for the heirloom lamp in her home as well as a familial past.

The first step of the uncovering process instigated rejuvenation of the lamp as an heirloom with "original retro" SCC that align the past and the present. The second step, leavening, strengthened these subtexts and allowed the lamp to gain new FM with Sanem's family as she integrated it into the "corner of old" (eski köşesi) in her family room (figure 6). Corner of old (in general and in Sanem's home) is an assembly of heirlooms, antiques, flea market finds, or store-bought replicas deemed to be more urbane, desirably old, or nostalgic. Unlike corners of the Orient that imply a rural past, these spaces manifest their owners' high cultural capital and urban roots. Combining an "antique" iron, a red-framed vintage mirror, a new chair reminiscent of the 1960s, and an "original" sideboard, Sanem's corner revives the spirit of the era, reflecting and imbuing

\section{FIGURE 6}

\section{SANEM'S DESK LAMP IN HER “CORNER OF OLD” (ESKI KÖSSESI)}

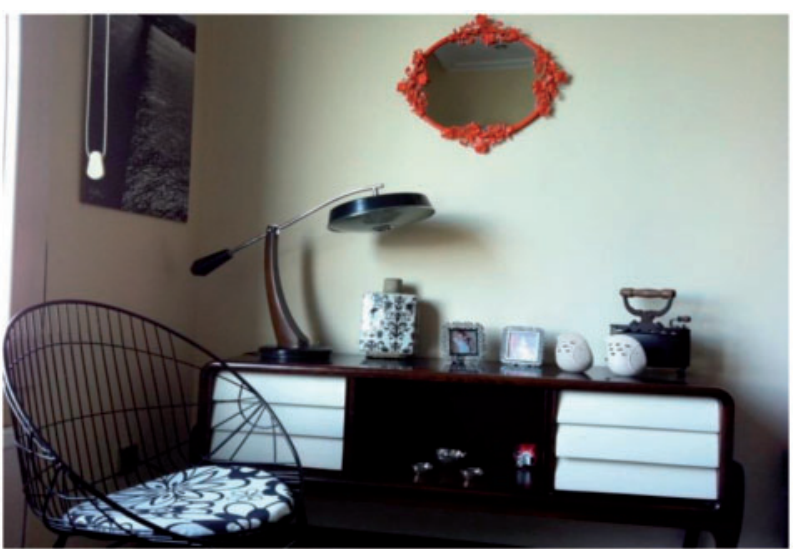

her own tastes (and HSC) into the rejuvenated lamp while strengthening its $\mathrm{E}_{\mathrm{IDV}}$ :

We put it there [the family room] .... I have this corner of old there.... The lamp is on a sideboard, from the 60 s I think, we bought it from a vintage goods store. Near the lamp, we have our black-and-white childhood photos on the sideboard. I put a retro-chair in the corner. It is the trendy, modern chairs of $60 \mathrm{~s}$, like in old Turkish movies. It is round, metal, big with a cushion in black-and-white retro fabric. (Sanem, 29, F)

The market inspires the lamp's leavening in guiding the creation of this multi-temporal space:

The trend is to bring the modern and the classic together. Retro style of 1970 s came back to the decoration scene.... Geometric and floral patterns together with bright colors bring warmth to our living spaces. Black, red, fuchsia, purple, and lemon yellow are favorite colors. (evdose.com, May 5, 2009)

In this corner, the lamp sheds its professional functions and becomes a source of light to nurture the family rituals in the making, such as watching movies. At the heart of the home, the lamp accumulates SFM from the past, the present, and hopefully the future ("they will like it") to link the three family generations (the grandfather, Sanem and her husband, and their future children):

The family room is now cozy ... our energy is in that room. It's alive, a living space.... Since it is very cozy, people prefer sitting there, especially guests in our age group. We sit there with the lamp.... When we watch movies, we turn off the other lights and keep the lamp on. I would like my 
children to have them all [the lamp and the objects in the corner]. They will like it [the lamp], I guess. (Sanem, 29, F)

While the literature depicts older generations as creators and transmitters of family legacy (Finch and Mason 2000; Marcoux 2001; Price et al. 2000) and heirs as guardians of this already written history (Curasi, Arnould, and Price 2004; Curasi et al. 2004; McCracken 1988), we found that heirs can also select, construct, and legitimize the embodiments of their ancestral past while materializing their individuality in the present. The deserted heirlooms, free from bonds to a past that "lock them into a time-space freeze" (Gregson and Crewe 2003, 173), are uncovered by a twostage compositional transformation that reinscribes their materialities with reanimated stories of the past and new stories of the present and the future.

Refreshing. An heirloom that has rich, well-rehearsed stories of origin and is well integrated into the heir's present life might face threats of material decay, have its desirable SCC weakened, or become contaminated with negative subtexts. In these cases, it needs rejuvenation to refresh its material and symbolic components. Refreshing (figure 2) can entail updating, which helps heirlooms stay timely, or reauthenticating, which realigns heirlooms with their heirs' imaginaries of a nostalgic past.

Updating-oriented compositional and material transformations bestow the heirloom with functions similar to its original ones, making it easier to recall and share its stories of origin. For instance, material alterations aligned the material form, FM, and SCC of Filiz's "old-fashioned" necklace, turning it into a more "me" and "trendy... like the ones in shops" necklace that she could "wear happily" and pass along. Beril and her mother, however, updated their heirloom sheet to fend off its material decay. The material transformations and the lace crafted by her mother refreshed the sheet's aesthetic looks and materiality. Instilled with Beril's present without "betraying the past," the renewed sheet moves on to the future:

I did not feel guilty ... it would die, you know. It looked worn and old. It is prettier now.... It is like we snatched it from the past. I fell in love with it again. I feel reconnected with my grandmother. I will be able to use it for longer. (Beril, 35, F)

The second form of refreshing, reauthenticating, (re)affirms heirlooms' connections to a desirable past reconstructed in the present. Yeliz fondly remembers her grandfather-her idol with "refined taste and education." His distinctive home, decorated in the 1950s high style with white upholstery, hand-carved furniture frames, and silver ornaments, was her safe haven (top photo in figure 7). Yeliz remembers playing there, "skidding on the carpet with the coffee table." When her grandparents' death threatened Yeliz's memories, she took their carpets,

\section{FIGURE 7}

\section{YELIZ'S HEIRLOOMS AT HER GRANDPARENTS' (TOP) AND IN HER LIVING ROOM (BOTTOM)}
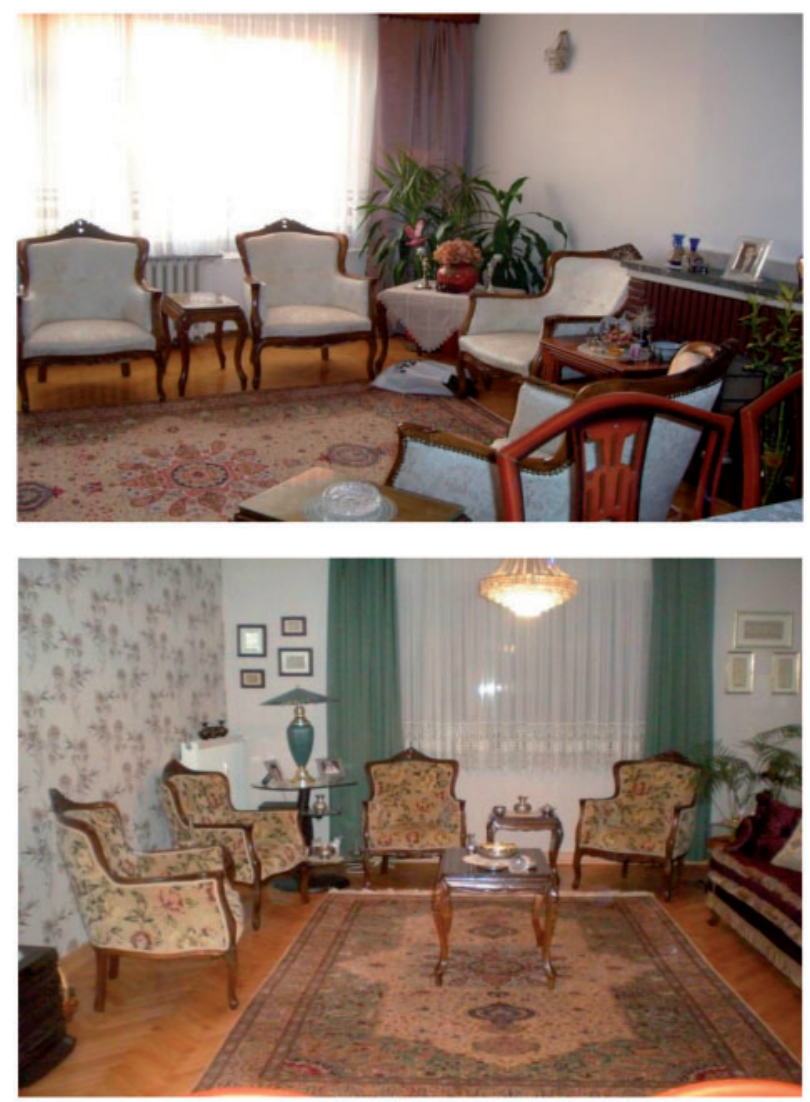

furniture, silverware, and chandeliers to redecorate her living room (bottom photo in figure 7).

To recreate her nostalgic sanctuary and keep the ancestral meanings alive, Yeliz kept her heirlooms as an ensemble because their essence was most pronounced as a set:

I got the whole set, furniture, carpets, silver, and all.... They [the objects] have been with us since my grandpa's first job.... My whole childhood was there. We used to turn the coffee tables over and skid on them. There are scratch marks. I have photos taken there.... Now they [the furniture and other objects] live in my living room. I am very happy. I claimed my memories, my past. I can show them to my guests and tell my son about them. I hope he understands. (Yeliz, 41, F)

Yeliz worked diligently to match the ensemble to her imaginary of the era and strengthen its SP-SCC: to replicate "how they were originally used then," she separated the heirloom sideboard from the glass cupboard; she preserved the armchairs' handcrafted wooden frames "full of scratches from our games" but hired a craftsman, "an old 
Ottoman gentleman," to replace the materially flexible light and plain upholstery with a darker and patterned one:

The fabric of the chairs was worn. I changed it. (Yeliz)

Interviewer: You preferred to replace them with a patterned, darker one....

I couldn't find the original.... Well, this one matched the antique carpet. The chairs now suit the atmosphere of the old. I changed the wallpaper too. I had a couch custommade. These crystals are mine. I love the silvers but these crystals ... beautiful and shiny. Silver is tough, strong, does not spoil easily. It is better to reflect the past but not beautiful like the crystals. I put my crystals on top of the silver cups. They look better now; the silver strengthens the crystal, the crystal beautifies the silver. (Yeliz)

Yeliz's transformations left her own mark on the heirloom set. Together with the changes in heirloom objects, the new wallpaper boosted the set's perceived antiquity in the sense of 1950 s modernity as imagined by her. Other new elements from the market such as the couch and crystals "completed" the heirloom ensemble by matching it to her aesthetic tastes and implanting the spirit of the present in the living room. Combining her grandfather's and her own modern sensibilities, Yeliz's set reaches into the future with her son if "he understands."

As Yeliz's transformations link her heirloom ensemble to multiple temporalities, the tension arising from her wish to reclaim the past and revive the traditional while being modern is resolved, albeit temporarily. Yeliz's incessant monitoring of decoration magazines and stores reveals new sensibilities in homemaking, attaching her "authentically old" heirloom set with unwelcomed SN-SCC. Specifically, the market condemns mish-mashing of styles and colors:

Using too many flower patterns together can be risky.... You need to combine a wallpaper or carpet with flamboyant patterns with more natural objects .... Too many patterns in a room create chaos and confusion. (evdose.com, January 22, 2011)

Yeliz's ensemble, despite its rich FM and desirable SCC, now clashes with the aesthetic styles in current decoration: the dark material of the upholsteries combined with the patterned wallpapers look old in an "exhausting and crowded" way. Seeing that her heirloom set's inalienability is in jeopardy, Yeliz is planning new transformations (e.g., replacing the upholsteries) to keep her heirlooms "authentically old" amid these dynamic market forces.

Unlike McCracken's (1988) curators who value heirlooms as archives, whose preservation is a duty to one's family, participants like Filiz or Yeliz want to connect to their ancestors and the past while holding on to their individuality and pursuit of the new. Refreshing helps these heirs by updating and/or reauthenticating their heirlooms. The new commodities (e.g., new couch, pendant) used in this process are not just "bit players" (McCracken 1988,
49) but important components that increase heirlooms' material and symbolic coherence, fitting them to current taste regimes. They help preserve inalienability by enhancing heirlooms' multi-temporality.

Reconciliation. The final rejuvenative process includes compositional and material transformations that reunite heirs with their heirlooms, which, despite having rich ancestral meanings, have been temporally and spatially distanced from the family.

Reconciliation can entail de-fossilizing or revival of heirlooms that are "fossilized" (Chevalier 1999)—not used or gazed at in ways that preserve their meanings. Sevgi reconciled with her cigarette box through a multi-temporal narrative and compositional work that slowly strengthened the box's potentially desirable but weak SCC while weakening its SN-SCC: enhancing the box's appeal for her daughters by stressing its form authenticated in the market, giving up its original use for a new one for her daughters, and narrating its stories of origin. The de-fossilized box carries both ancestral meanings and Sevgi's story of becoming a liberated divorcee, a nonsmoker, and a caring mother while also accommodating her daughters.

Ezgi's silk was fossilized because she had never used it herself. The heirloom silk had a touching story of origin: her aunt, the caretaker in Ezgi's family after their mother died, had bred silkworms and processed the silk into fabric. Lying unused and out of sight, the silk could not relay its stories and "no one would know or speak about my aunt." Her daughters' marriage provided an opportunity for the silk's revival: the handwoven and high-quality silk, rare and valuable in the market (Federico 2009), could fit their more upscale lifestyles:

I never used the silk covers, always kept them hidden .... Then I said I will give them to my daughters. I tell them "You use them, don't hide them"... Sanem's guests ask about them, their beauty. It's a different feeling. Sanem can tell their story, say it's from my mom's aunt. No one would have seen them if hidden. (Ezgi, 57, F)

As evidenced by the existence of businesses specializing in conservation, storage and protective framing are popular practices for preserving valuable heirloom textiles. Instead of engaging in such curatorial practices, Ezgi worked like a craftsperson to transform the silk materially into a functional bedcover and tablecloths (figure 8). This transformation de-fossilized her invaluable silk fabric's ancestral FM and highlighted its desirable SCC:

I turned it into covers for the bed that Sanem could use. I gave the remaining fabric pieces to an embroiderer who made these motifs ... but, I picked the patterns from an antique motif book. I knit lace for the fringes. Now, they are more beautiful, valuable. Sanem can say "it's from my great aunt, mom embroidered these." (Ezgi, 57, F) 


\section{FIGURE 8}

\section{EZGI'S SILK FABRIC TRANSFORMED INTO A BEDCOVER AND TABLE COVERS}
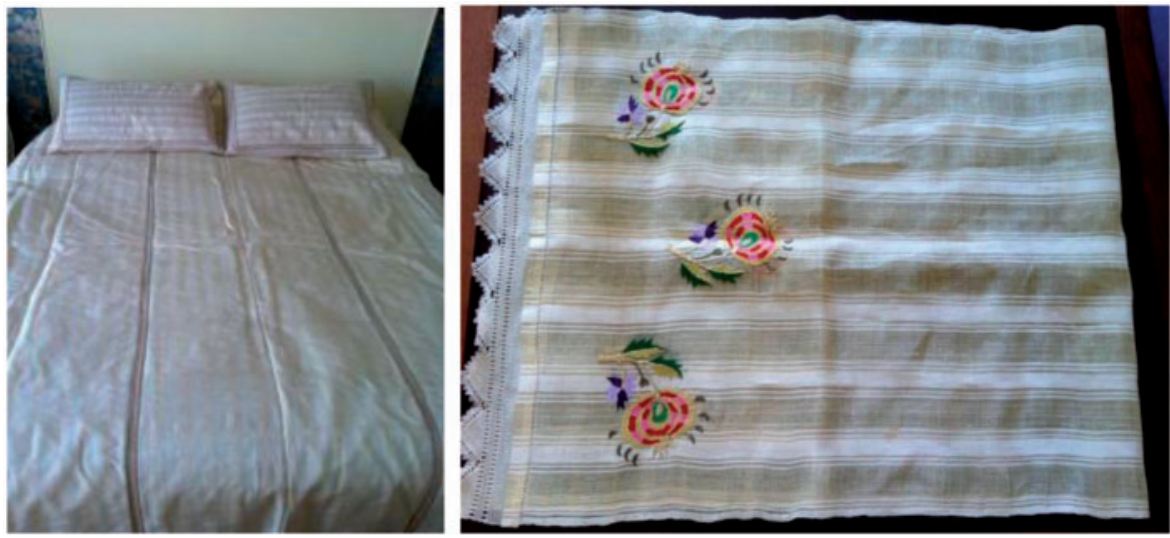

The silk's $E_{\text {DNA }}$ was preserved with Ezgi's balanced use of market resources and her craft skills: cutting the homogeneous silk fabric into pieces, hiring skillful labor to embroider the delicate material, and implanting the silk with her HSC by weaving lace across the fringes. Connecting the silk to focal household practices, materialities, and spaces in Sanem's home (Shove and Pantzar 2005), Ezgi's rejuvenation de-fossilized the "sublime and unique heirloom from my family." Bestowed with a "light, plain, and beautiful form" to be used for "special occasions or guests," the renewed silk fits Sanem's simple style and homemaking practices.

The other process of reconciliation is hibernation: a deliberate passivization of heirlooms to weaken their negative subtexts and reveal their potential life. Notably used for heirlooms with rural SCC, hibernation temporally and spatially distances heirlooms from heirs to erase their strong undesirable past and present SCC. Consider Ferhunde's helke (a copper container used in villages) that she took with her to the city during her migration:

When we moved here, we sold most of what we had from the family .... He [her husband] sold the coppers at the market, for a pittance. And we left a lot back at home.... This [helke] was from my dowry.... Back then, every bride [in her village] had something like that. We used to put it over the fire to boil water or cook aşure [Noah's pudding] . . lots of memories .... In the city, we did not have an appropriate space. What would you do with it in the city? It would crowd my home. I do not like disorder ... so I did not know what to do. It would go like the others. I put it in the basement, kept it there. But, now, a lot of people in the city have these copper things. My helke is thicker and better than what they sell in the stores now .... I moved it back home. I had it coated, polished.... I put plants in it, put it here. (Ferhunde, 56, F)
In the city, the helke was exposed to the urban gaze, which attached it with SN-SCC. Between these new subtexts and its desirable FM, Ferhunde's helke became "disorder," a reflection of rural imagery in her new urban life. Having no competence to alter the copper, Ferhunde prevented its alienation by distancing it from her new life and put it in the basement. This passivity opened the helke to desirable subtexts as the market started reproducing copper objects for urban homes. Now, better adjusted to the city unlike "those living in the village," Ferhunde reconciled with her helke by turning it into a flowerpot for her living room (figure 9). Combined with modern pots and a traditional chest, the helke blends in in her urban home while discreetly materializing her rural roots through the soil and green plant it hosts.

Similarly, Neslihan's headdress hibernated for a while as she planned its rejuvenation. Despite its splendor and desirable FM, the cap's social history was linked to the rural roots of her immigrant parents, who also welcomed its planned transformation:

It is beautiful, silver with engravings. I saw it at my grandma's and said "don't give it to anyone, I will get it." She died, I got it right away, put it away. I mean, I want to do something with it....We talked about it with my mom and grandma. (Neslihan, 45, F)

Raised in the city, Neslihan pursues a modern life by adapting herself to urban tastes and Western culture. The otantik headdress has no place in her current life:

I am modern. I try to enjoy life, not the domestic stuff . . . . I play tennis, I sing. I like going to antique bazaars and flea markets... I I saw this mirror in one. They [artisan shops] make silver mirrors, with engravings on the back to hang on the walls .... I thought I could use my cap like this, turn it 


\section{FIGURE 9}

\section{FERHUNDE'S HELKE AS A FLOWERPOT}

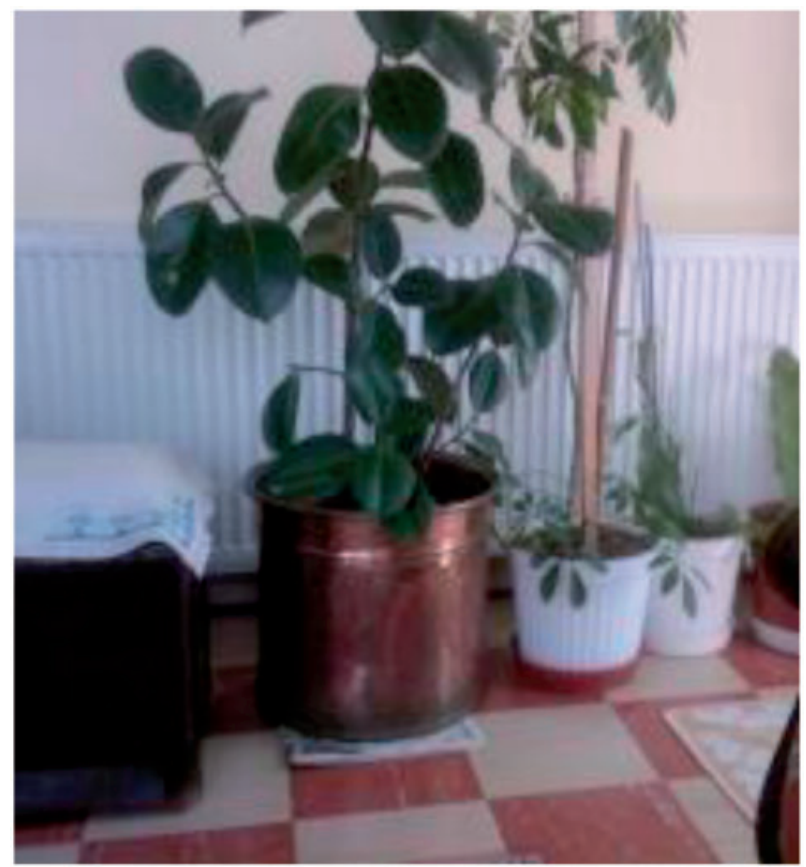

into a hand mirror ... put it on my vanity and look at it every day, when I move to my own home. (Neslihan, 45, F)

The headdress's delicate material and $\mathrm{E}_{\mathrm{IDV}}$ complicate its transformation. Attachment of the mirror will obscure its original function and weaken its negative SCC without spoiling its essence. Meanwhile, rejuvenation plans are discussed in the family, affixing new FM to the heirloom. Neslihan actually talks more about its planned metamorphosis than stories of its origin, turning the heirloom into as much a symbol of her modern urbanite present as of her ancestral past. The headpiece reaches out into the future as Neslihan imagines its use in her future home.

Resilient negative SCC may require longer hibernation and unorthodox alterations. Consider Mehtap's CD. For Mehtap too, her family's rural divans, carpets, and copper utensils are out of place in her modern, urban life trajectory:

I love my past, a little romantic perhaps. I value the emotional link.... I have a cute copper ewer, may get a few coppers from mom, her helke, perhaps. But, I cannot take anything else. At home, I keep it simple, soft light forms .... I don't have a corner of the Orient .... I have this CD. One of the elders renovated their home in our village, built a corner with heirlooms, otantik items, coppers from wall to wall, very beautiful. We have it all on the $\mathrm{CD}$, I can show you ... these objects, from my grandma's, my mom's time in the village, reclaimed and displayed, very otantik. (Mehtap, 27, F)

Inspired by the imageries in antique bazaars and vintage stores, Mehtap longs for an urban family past that she cannot have. For her, her ancestors' material heritage belongs to corners of the Orient or village houses. Mehtap negotiates the materiality of her inheritance through the CD that digitalizes and archives the heirloom objects in a renovated rural family home. The CD helps her reminisce at a safe distance from the objects and becomes a compact legacy: inalienable as it conveys SFM anywhere even though it ironically enables their reproduction.

The reconciliation process connects passive heirlooms to new configurations that give them new functions and remove their negative SCC while accentuating their desirable ancestral meanings and subtexts. While the literature views preservation of an heirloom's original uses and form as crucial for its reactivation (Epp and Price 2010), processes of de-fossilizing and hibernating can revive an heirloom through radically new forms and/or functions. Moreover, in contrast to the weakening and alienating effects of passivity (Bradford 2009; Curasi et al. 2004) that fossilize or freeze heirlooms and lock their meanings (Chevalier 1999), hibernation provides a period of deliberate passivity for heirlooms that actually prevents their alienation.

To summarize, rejuvenation processes include uncovering forgotten heirlooms by inscribing them with new stories of the past and the present; refreshing heirlooms' materiality and meanings to defend against alienation threats; and reconciling with passivized heirlooms by removing their negative subtexts and enhancing their uses. The transformations used in these processes attach to heirlooms a zeitgeist value, at times by radically changing their forms, uses, and meanings. Rejuvenated heirlooms objectify a desirable past, fit into their heirs' present, and embrace the future with their renewed materiality, aesthetics, functions, and social stories.

\section{DISCUSSION AND IMPLICATIONS}

Heirlooms, usually regarded as stable identity anchors and meaning transmitters, become embodiments of change through rejuvenation - a process of revival that is bound by the heirloom's essence-materiality nexus, the heir's competence, and market forces. The scripts and imageries of modernity and the concomitant quest for change inscribe heirlooms with multiple and usually conflicting meanings. Specific to the Turkish consumptionscape, heirloom rejuvenation takes place amid new-old and urban-rural tensions, ideals promoting domestic craftwork, and a taste for the distinctive old, all of which shape contemporary notions of aesthetics, functionality, and authenticity. 
Rejuvenation, marked by a dynamic interplay of change and preservation, helps consumers negotiate their heirlooms' conflicting meanings by boosting heirlooms' zeitgeist value, making them also objects of the present and facilitating their journey into the future. Hence our study challenges the idea that "modernity destroys tradition" (Beck et al. 1994, 91) and supports the view that the two are "mutually reinforcing" (Gusfield 1967, 356). While ideals and institutions of modernity provide heirloom objects with new meanings and potential lives, heirlooms reify these ideals/institutions by reproducing and materializing them in their rejuvenated forms.

Another insight is the dynamic multi-temporal potential of heirlooms. An heirloom's essence-materiality nexus, while partially limiting its rejuvenation, is open to change and shaped by heirs' reflexive multi-temporal imaginings: Yeliz tries to capture the ever-elusive then-modern and now-modern in her heirloom set; current retro imageries reconstruct the essence of Sanem's lamp; the market authenticates Hale's desirably otantik pillowcases' color and patterns. This has two implications. First, the essence of an heirloom is shaped not only by its biography in the family (Curasi et al. 2004; Kopytoff 1986) but also by its macro sociocultural history (Appadurai 1986), its present (e.g., how it is used, current holders, position in the market), and its future (e.g., what it can be, how it can be used, future heirs). The transformations we have identified further insert heirlooms into the present by enhancing their functions and visibility. As their contact with the present and future family increases, rejuvenated heirlooms gain value and new meanings. Second, while inalienability makes "the past a powerful resource for the present and the future" (Weiner 1985, 224), rejuvenation turns the present and the future into key resources for inalienability and (re)valuating the past. Heirlooms live dynamic lives and stay inalienable, not just by moving in and out of passivity and obtaining additional meanings and uses attuned to existing ones (Bradford 2009; Chevalier 1999; Curasi et al. 2004; Epp and Price 2010, Marcoux 2001; McCracken 1988; Price et al. 2000), but also by fitting to the zeitgeist as they lose certain meanings or uses and gain alternative ones that can be radically different from the previous ones.

Our findings also imply that heirlooms, in addition to being parts of macro networks of materials, discourses, spaces, and practices (Appadurai 1986; Epp and Price 2010), might be perceived as composites of modular symbolic and material components rather than as uniform entities. Understanding how an heirloom's status and relations with consumers change thus requires more than considering changes in family identity or home networks (Curasi et al. 2004; Epp and Price 2010, McCracken 1988); it requires considering heirloom objects as material and symbolic ensembles whose biographies are shaped by the heir's life trajectory, broader sociohistorical shifts, and the market.

\section{Heirloom as an Objectification of Becoming}

Social life and identity are always in the process of becoming, and "the doings of humans and nonhumans combine to make the social site the scene of continuously metamorphosing orders and perpetually performed, often evolving, activities" (Schatzki 2002, 189-90). In line with these views, we showed how heirlooms materialize consumers' becoming and how heirloom consumption comes to accommodate change. Our findings testify to consumers' experience of heterogeneous time (Chatterjee 2001) and extend Schau et al.'s (2009) study on elder consumers' weaving across time to manage their identities.

Driven by a quest for authenticity and self-expression in a world of fragmentation and mass consumption (Arnould and Price 2000; Rose and Wood 2005), consumers turn to their heirlooms as objects "from family," "original," "real," and "with character." Yet in their endless becoming (Heidegger 1962; Schatzki 2002), consumers transform rather than merely preserve their heirlooms. Heirlooms, in shedding their skins to continuously adapt and become rejuvenated without losing their heirloom status and heritage value, help consumers drop the unwanted aspects of their past and present, and anchor their skills in change. Rejuvenation links heirlooms and their heirs to multiple temporalities simultaneously and iteratively.

Inspired by the imageries and ideologies of modernity, heirs adopt a future-oriented gaze or an aesthetic sensibility. Such a gaze does not erase the past or the heirlooms' previous uses and meanings, but rather it highlights what an heirloom can become over and above (and sometimes in spite of) what it has been. The present, in this process, is a medium for connecting and negotiating the past(s) and the future(s) embodied in heirlooms: it summons and transfers certain imagined pasts linked to desirable prospective futures while leaving others to hibernate and preventing others from being recalled at all. Rather than being a danger (Price et al. 2000), the present bears opportunities for heirlooms. The zeitgeist prevails in rejuvenation: in popular commodities that heirs refer to in aestheticizing heirlooms, in creation of new functions for heirlooms, or in craft methods that imbue heirlooms with the heir's self. As a consumer's present shifts, the continuity in heirlooms comes more from their potential to change and reconnect to this dynamic zeitgeist than their fixed indexical links (Grayson and Shulman 2000) to the past.

Thus heirlooms identified in this study are not valued solely for their pasts, but also because they embody consumers' individual selves and ability to become. In crafting their heirlooms' rejuvenation, Sanem, Ezgi, and Yeliz did not just build on their family histories but also used their current identities, competences, and aspirations for the future, making stories of transformation as important as stories of origin. Akin to stories of "discovery, survival, resurrection, and refinement" that revive beloved brands 
(Muniz and Schau 2005), stories of transformation, of skillful save, enrich heirlooms by mystifying their survival and marking them with their heirs' presence. If stories of origin sacrilize and legitimize heirlooms by highlighting their imagined past and ancestral links (Curasi, Arnould, and Price 2004; Curasi et al. 2004; Price et al. 2000), stories of rejuvenation reinstate heirlooms' legitimacy for the present and future by incorporating the current and future heirs into their life stories.

To summarize, in their perpetual transformations to connect the past, the present, and the future, heirlooms objectify the heir's (and the new family's) ability to change. The active and playful heirloom rejuvenation practices described here resemble contemporary forms of craft consumption.

\section{Heirloom Consumption as Craftwork}

Rejuvenation, a proactive and creative way of consuming heirlooms, endows heirs with agency, a capacity to make a difference (Giddens 1984). Compared to the dutiful and archiving curatorial consumer who deserts or accommodates her heirlooms as they are, the playful excavators we have unveiled have more capacity to shape their heirloom consumption, under certain conditions: Yeliz continuously works on her heirloom set to replenish its connections to the past as her present changes, Beril experimented on her "magic fabric," and Ahu acted on her "huge responsibility" coffee grinder.

These heirs act like craft consumers who recontextualize and transform objects (Miller 1987) by exerting control on and instilling them with emotions, skills, and knowledge (Campbell 2005). Specifically, material and compositional transformations align with Campbell's notion of "craft as ensemble," or using one's skills to create ensembles of objects, styles, and materials with the help of the market. In this process, heirs' competence in craft "objectifies their charismatic power through material practices" (Douny 2011, 404), turning the renewed heirloom into an embodiment of the heir's individuality. The investment of competence protects heirlooms against authenticity threats. In their crafted form, heirlooms carry the current (and sometimes future) heir's mark and, as such, better objectify the future and resist alienation.

Transformative practices thus turn heirloom consumption into a type of craftwork that manifests and legitimizes consumers' competence. Conversely, the craft aspects of rejuvenation turn heirloom consumption into an act of creation (Anderson 2011) and reinscribe heirlooms with new stories, enhanced materialities, and individual identity markers. Challenging the view that individuality should be sacrificed for belongingness to something grand (McCracken 1988), heirloom rejuvenation anchors consumers to a desirable material reality (Sennett 2008) by creating personalized heirlooms while strengthening in-family connections. The marketplace catalyzes and legitimizes such rejuvenation.

\section{The Market as a Threat and an Opportunity for Inalienability}

Whereas the literature highlights the dangers of the market for heirlooms, we have revealed its role in creating, transforming, and legitimizing heirlooms. The market bears both potentials for inalienability: it can alienate heirlooms by highlighting their exchange value and potential substitutes, but it can also strengthen inalienability by fortifying the bonds between consumers and their heirlooms.

Our findings align with and expand on studies underlining the market's capacity to instill objects with meaning, value, and inalienability (Bradford 2009; Epp and Price 2010). It is a source of inspiration, competence (Watson and Shove 2008), skill and technique (Fromm 1997), and technology (Sutton 2009) for the heirs. The market alludes to continuous change, encouraging consumers to monitor and alter their heirlooms. It creates in consumers a "material consciousness" (Sennett 2008) to recognize the heirlooms they can alter (e.g., Sanem's eye for the desk lamp) and a "practical consciousness" (Giddens 1984) to act on them (e.g., Ezgi's craft skills and inspiration for embroideries).

We contribute to the discussion on the role of the market in consumption of familial objects (Epp and Price 2008; Epp and Velagaleti 2014) by drawing the boundaries for the market's involvement in heirloom rejuvenation. Our finding that the profane marketplace, rather than harming heirlooms' authenticity (Belk et al. 1989; Weiner 1992), can remove heirlooms' unwanted connotations and attach them with new desirable ones (provided the heirs are invested in the process) challenges the much debated sacred/ profane distinction. The market can indeed be intrusive and dangerous for heirlooms unless controlled by the heirs. The perceived lack of control emerges when heirs feel incompetent in the rejuvenation domains promoted by the market. Heirs' involvement in the process authenticates it as craftwork (Campbell 2005; Miller 1987) and moderates the market's role. Without such investment, a potentially creative transformation turns into an act of imitation that endangers the authenticity of rejuvenated heirlooms.

\section{CONCLUDING REMARKS AND FUTURE RESEARCH}

Given our findings on rejuvenation, future research might consider heirloom consumption as a process of negotiation and interplay of multi-temporal forces embedded, beyond family history, in broad sociohistorical contexts. Similarly, consumer research should give more voice to consumers' experiences of becoming by going beyond 
identity projects and focusing on consumers' life trajectories.

Particularities of the Turkish milieu clearly nurtured specific aspects of our findings. However, it is also clear that heirloom transformation is a common but perhaps unearthed phenomenon, be it in transitional societies witnessing urbanization and the emergence of new middle classes, or the more stable Western world, as evidenced, for example, by the popularity of TV shows such as Something Borrowed, Something New.

The playful and creative heirloom consumption revealed in this study points to new research directions. First, the consumer competence that is central to craft-like rejuvenation processes entails cultural capital that pertains to social class. Hence one promising research avenue would be to explore the relation between heirloom rejuvenation and social class. Second, heirloom transformation resembles the creation of assemblages, with heirlooms as composite objects with symbolic and material parts. Thus assemblage theory may be a fruitful analytical lens through which to explore heirlooms and heirloom consumption. Third, our findings on heirlooms' essence-materiality nexus imply that bringing forth the materiality in consumer research can reveal new aspects of heirloom consumption.

Moreover, the frequent appearance of fabrics, lace, and utensils in our data or the emergence of specific transformation methods may reflect the fact that most of the participants were female. A gendered analysis of heirloom rejuvenation processes could shed new light and might explain, for example, Gürkan's hesitance to rejuvenate his cufflinks.

More research is also needed to understand the relation between the strength of family ties and the willingness to rejuvenate heirlooms. Consumers whose families exert extensive influence on their lives might be more inclined to use heirloom rejuvenation to manifest their own individuality amid these strong ties. Alternatively, the strong presence of the family in one's life in immaterial ways might decrease the importance of the family's material expressions, making consumers bolder and more experimental with their heirlooms. Our research provides limited insight on how different members of the family react to the alteration of heirlooms. Is Sanem's husband happy with the new desk lamp? Is Mehtap's CD accepted by other family members? Future research might focus on heirloom rejuvenation as a process of in-family negotiations to show how different members interpret the transformed heirlooms.

To conclude, rejuvenated heirlooms, imbued with the heir's mark and zeitgeist value, objectify the heir's life trajectory and process of becoming, in addition to their heritage value and links to a familial past. Rejuvenation thus helps consumers negotiate the past, the present, and the future while enhancing their heirlooms' multi-temporal nature. This playful craft-like consumption of heirlooms poses an alternative to curatorial consumption in protecting inalienability. Similarly, the marketplace can actually bear opportunities for heirlooms' inalienability by enhancing and guiding their rejuvenation.

\section{DATA COLLECTION INFORMATION}

From the beginning of our research, the first author conducted all the in-person fieldwork from late 2008 until late 2011. The first author provided the field notes, interview transcripts, documents in print and social media, photographs, and a video CD (recorded previously by a participant's family); the second author contributed occasionally with her own notes and documents. The data were first read and analyzed separately by both authors. Both authors met on multiple occasions to discuss the data and compare and consolidate their analyses. The final work was jointly authored.

\section{REFERENCES}

Alesina, Alberto and Paola Giuliano (2010), "The Power of the Family," Journal of Economic Growth, 15 (June), 93-125.

Anderson, Anne (2011), "The 'New Old School': Furnishing with Antiques in the Modern Interior-Frederic, Lord Leighton's Studio-House and its Collections," Journal of Design History, 24 (December), 315-38.

Anadolu, Ajansı (2010), “Gaz Lambaları Yeniden Evlerin Baş Köşesinde,” November 20.

Appadurai, Arjun (1986), "Introduction: Commodities and the Politics of Value," in The Social Life of Things: Commodities in Cultural Perspective, ed. Arjun Appadurai, Cambridge, UK: Cambridge University Press, 3-63.

Arnold, Stephen J. and Eileen Fischer (1994), "Hermeneutics and Consumer Research," Journal of Consumer Research, 21 (June), 55-70.

Arnould, Eric J. and Amber M. Epp (2006), "Living Legacies: Exploring Influences on Family Consumption Behavior," in Advances in Consumer Research, Vol. 33, ed. Connie Pechmann and Linda L. Price, Duluth, MN: Association for Consumer Research, 82-86.

Arnould, Eric J. and Linda L. Price (2000), "Authenticating Acts and Authoritative Performances," in The Why of Consumption: Contemporary Perspectives on Consumer Motives, Goals, and Desires, ed. S. Ratneshwar, David G. Mick, and Cynthia Huffman, New York: Routledge, 140-63.

Arsel, Zeynep and Jonathan Bean (2013), "Taste Regimes and Market-Mediated Practice," Journal of Consumer Research, 39 (February), 899-917.

Artıkoğlu, Pınar (2006), “1950-1970 Arası Süreçte Sosyal Yaşam ve İç Mekanın Değisenleri," PhD diss., Faculty of Architecture, Mimar Sinan Fine Arts University, İstanbul, Turkey.

Aytaç, Ahmet M. (2007), Ailenin Serencamı: Türkiye’de Modern Aile Fikrinin Oluşması, Ankara: Dipnot Yayınları.

Bauman, Zygmunt (2000), Liquid Modernity, Cambridge, UK: Polity.

Baumeister, Roy F. (1987), "How the Self Became a Problem: A Psychological Review of Historical Research," Journal of Personality and Social Psychology, 52 (January), 163-76. 
Beck, Ulrich, Anthony Giddens, and Scott Lash (1994), Reflexive Modernization: Politics, Tradition and Aesthetics in the Modern Social Order, Stanford, CA: Stanford University Press.

Belk, Russell W. (1990), "The Role of Possession in Constructing and Maintaining a Sense of Past," in Advances in Consumer Research, Vol. 17, ed. Marvin E. Goldberg, Gerald Gorn, and Richard W. Pollay, Provo, UT: Association for Consumer Research, 669-76.

- (1992), "Moving Possessions: An Analysis Based on Personal Documents from the 1847-1869 Mormon Migration," Journal of Consumer Research, 19 (December), 339-61.

Belk, Russell W., Güliz Ger, and Soren Askegaard (2003), "The Fire of Desire: A Multisited Inquiry into Consumer Passion," Journal of Consumer Research, 30 (December), 326-51.

Belk, Russell W., Melanie Wallendorf, and John F. Sherry (1989), "The Sacred and the Profane in Consumer Behavior: Theodicy on the Odyssey," Journal of Consumer Research, 16 (June), 1-38.

Bhabha, Homi K. (1994), The Location of Culture, London: Routledge.

Borgerson, Janet L. (2014), "The Flickering Consumer: New Materialities and Consumer Research," in Consumer Culture Theory (Research in Consumer Behavior), ed. Russell W. Belk, Linda Price, and Lisa Peñaloza, Bingley, UK: Emerald Group, 125-44.

Bourdieu, Pierre (1984), Distinction: A Social Critique of the Judgment of Taste, Cambridge, MA: Harvard University Press.

Bozdoğan, Sibel and Reşat Kasaba (1997), "Introduction," in Rethinking Modernity and National Identity in Turkey, ed. Sibel Bozdoğan and Reşat Kasaba, Seattle, WA: University of Washington Press, 3-14.

Bradford, Tonya W. (2009), "Intergenerationally Gifted Asset Dispositions," Journal of Consumer Research, 36 (December), 93-111.

Campbell, Colin (2005), "The Craft Consumer: Culture, Craft, and Consumption in a Postmodern Society," Journal of Consumer Culture, 5 (March), 23-42.

Canniford, Robin and Avi Shankar (2013), "Purifying Practices: How Consumers Assemble Romantic Experiences of Nature," Journal of Consumer Research, 39 (February), 1051-69.

Chakrabarty, Dipesh (2007), Provincializing Europe: Postcolonial Thought and Historical Difference, Princeton, NJ: Princeton University Press.

Chatterjee, Partha (2001), "The Nation in Heterogeneous Time," Indian Economic and Social History Review, 38 (December), 399-418.

Chevalier, Sophie (1999), "The French Two-Home Project: Materialization of Family Identity," in At Home: An Anthropology of Domestic Space, ed. Irene Cieraad, Syracuse, NY: Syracuse University Press, 83-94.

Cieraad, Irene (2010), "Homes from Home: Memories and Projections," Home Cultures, 7 (March), 85-102.

Collins, Nathalie, Hanna Glaebe, and Jamie Murphy (2011), "Relationships Between Quintessence and Strong Word of Mouth Behaviour," paper presented at the Australia New Zealand Marketing Academy Conference, Perth, Australia.

Coole, Diana and Samantha Frost (2010), "Introducing the New Materialisms," in New Materialisms: Ontology, Agency, and
Politics, ed. Diana Coole and Samantha Frost, Durham, NC: Duke University Press, 1-43.

Csikszentmihalyi, Mihaly and Eugene Rochberg-Halton (1981), The Meaning of Things: Domestic Symbols and the Self, Cambridge, UK: Cambridge University Press.

Curasi, Carolyn F. (2006), "Maybe It Is Your Father's Oldsmobile: The Construction and Preservation of Family Identity Through the Transfer of Possessions," in Advances in Consumer Research, Vol. 33, ed. Connie Pechmann and Linda L. Price, Duluth, MN: Association for Consumer Research, 83-84.

Curasi, Carolyn F., Eric J. Arnould, and Linda L. Price (2004), "Ritual Desire and Ritual Development: An Examination of Family Heirlooms in Contemporary North American Households," in Contemporary Consumption Rituals: A Research Anthology, ed. Cele C. Otnes and Tina M. Lowrey, London: Erlbaum, 237-65.

Curasi, Carolyn F., Linda L. Price, and Eric J. Arnould (2004), "How Individuals' Cherished Possessions Become Families' Inalienable Wealth," Journal of Consumer Research, 31 (December), 609-22.

Dechaux, Jean-Hugues (2002), "Paradoxes of Affiliation in the Contemporary Family," Current Sociology, 50 (March), 229-42.

DeLanda, Manuel (2006), A New Philosophy of Society: Assemblage Theory and Social Complexity, New York: Continuum.

Douny, Laurence (2011), "Silk-Embroidered Garments as Transformative Processes: Layering, Inscribing and Displaying Hausa Material Identities," Journal of Material Culture, 16 (December), 401-15.

Eickelman, Dale F. (1998), The Middle East and Central Asia: An Anthropological Approach, Upper Saddle River, NJ: Prentice Hall.

Epp, Amber M. and Linda L. Price (2008), "Family Identity: A Framework of Identity Interplay in Consumption Practices," Journal of Consumer Research, 35 (June), 50-70.

—. (2010), "The Storied Life of Singularized Objects: Forces of Agency and Network Transformation," Journal of Consumer Research, 36 (February), 820-37.

Epp, Amber M., Hope J. Schau, and Linda L. Price (2014), “The Role of Brands and Mediating Technologies in Assembling Long-Distance Family Practices," Journal of Marketing, 78 (May), 81-101.

Epp, Amber M. and Sunaina R. Velagaleti (2014), "Outsourcing Parenthood? How Families Manage Care Assemblages Using Paid Commercial Services," Journal of Consumer Research, 41 (December), 911-35.

Esenbel, Selçuk (2000), "Türk ve Japon Modernleşmesi: 'Uygarlık Süreci' Kavramı Açısından bir Mukayese," Toplum ve Bilim, 84 (Spring), 18-36.

Favart-Jardon, Evelyne (2002), "Women's 'Family Speech': A Trigenerational Study of Family Memory," Current Sociology, 50 (March), 309-19.

Federico, Giovanni (2009), An Economic History of the Silk Industry, 1830-1930, Cambridge, UK: Cambridge University Press.

Finch, Janet and Jennifer Mason (2000), Passing On: Kinship and Inheritance in England, London: Routledge.

Fromm, Erich (1997), To Have or to Be, London: Continuum.

Fuchs, Christoph, Martin Schreier, and Stijn M. J. van Osselaer (2015), "The Handmade Effect: What's Love Got to Do with It?” Journal of Marketing, 79 (March), 98-110. 
Ger, Güliz and Russell W. Belk (1996), "I'd Like to Buy the World a Coke: Consumptionscapes of the 'Less Affluent World," Journal of Consumer Policy, 19 (September), 271-304.

Giddens, Anthony (1984), The Constitution of Society: Outline of the Theory of Structuration. Berkeley: University of California Press.

. (1990), The Consequences of Modernity, Cambridge, UK: Polity.

- (1991), Modernity and Self Identity: Self and Society in the Late Modern Age, Stanford, CA: Polity.

Grayson, Kent and David Shulman (2000), "Indexicality and the Verification of Irreplaceable Possessions: A Semiotic Analysis," Journal of Consumer Research, 27 (June), 17-30.

Gregson, Nicky and Louise Crewe (2003), Second-Hand Cultures, Oxford, UK: Berg.

Gusfield, Joseph R. (1967), "Tradition and Modernity: Misplaced Polarities in the Study of Social Change," American Journal of Sociology, 72 (January), 351-62.

Harnish, David (1993/1994), "The Future Meets the Past in the Present: Music and Buddhism in Lombok," Asian Music, 25 (1/2), 25th Anniversary Double Issue, 29-50.

Hecht, Anat (2001), "Home Sweet Home: Tangible Memories of an Uprooted Childhood," in Home Possessions: Material Culture Behind Closed Doors, ed. Daniel Miller, Oxford, UK: Berg, 123-45.

Heidegger, Martin (1962), Being and Time, New York: Harper \& Row.

Hurdley, Rachel (2006), "Dismantling Mantelpieces: Narrating Identities and Materializing Culture in the Home," Sociology, 40 (4), 717-33.

Kandiyoti, Deniz (1997), "Gendering the Modern: On Missing Dimensions in the Study of Turkish Modernity," in Rethinking Modernity and National Identity in Turkey, ed. Sibel Bozdoğan and Reşat Kasaba, Seattle: University of Washington Press, 113-56.

Kandiyoti, Deniz and Ayşe Saktanber (2002), Fragments of Culture: The Everyday of Modern Turkey, London: IB Tauris.

Karababa, Eminegül (2012), "Investigating Early Modern Ottoman Consumer Culture in the Light of Bursa Probate Inventories," The Economic History Review, 65 (February), 194-219.

Karadeniz, Esra and Ozlem Ozdemir (2009), "Entrepreneurship in Turkey and Developing Countries: A Comparison of Activities, Characteristics, Motivation and Environment for Entrepreneurship," MIBES Transactions, 3 (1), 30-45.

Kasaba, Reşat (1997), "Kemalist Certainties and Modern Ambiguities," in Rethinking Modernity and National Identity in Turkey, ed. Sibel Bozdoğan and Reşat Kasaba, Seattle: University of Washington Press, 15-36.

Keyman, Emin F. (2007), "Introduction: Modernity and Democracy in Turkey," in Remaking Turkey, ed. Emin F. Keyman, Plymouth, UK: Lexington Books, xv-xxvii.

Kopytoff, Igor (1986), "The Cultural Biography of Things: Commoditization as a Process," in The Social Life of Things: Commodities in Cultural Perspective, ed. Arjun Appadurai, Cambridge, UK: Cambridge University Press, 64-94.

Kozan, M. Kamil (1994), "Conflict Managements in Turkey," in Global Perspectives on Organizational Conflict, ed. Afzalur Rahim and Albert A. Blum, New York: Praeger, 135-52.
Kramer, Anne-Marie (2011), "Kinship, Affinity and Connectedness: Exploring the Role of Genealogy in Personal Lives," Sociology, 45 (June), 379-95.

Lastovicka, John L. and Nancy L. Sirianni (2011), “Truly, Madly, Deeply: Consumers in the Throes of Material Possession Love," Journal of Consumer Research, 38 (August), 323-42.

Latour, Bruno (2005), Reassembling the Social: An Introduction to Actor-Network-Theory, Oxford, UK: Oxford University Press.

Marcoux, Jean-Sebastien (2001), “The 'Casser Maison' Ritual: Constructing the Self by Emptying the Home," Journal of Material Culture, 6 (July), 213-35.

Mason, Jennifer (2008), "Tangible Affinities and the Real Life Fascination of Kinship," Sociology, 42 (February), 29-45.

McCracken, Grant (1988), "Lois Roget: Curatorial Consumer in a Modern World," Culture and Consumption, Bloomington: Indiana University Press, 44-56.

Miles, Steven (2001), Social Theory in the Real World, London: Sage.

Miller, Daniel (1987), Material Culture and Mass Consumption, Oxford, UK: Blackwell.

Moisio, Risto, Eric J. Arnould, and James W. Gentry (2013), "Productive Consumption in the Class-Mediated Construction of Domestic Masculinity: Do-It-Yourself (DIY) Home Improvement in Men's Identity Work," Journal of Consumer Research, 40 (August), 298-316.

Muniz, Albert M. Jr. and Hope J. Schau (2005), "Religiosity in the Abandoned Apple Newton Brand Community," Journal of Consumer Research, 31 (March), 737-47.

Nederveen Pieterse, Jan (1995), "Globalization as Hybridization," in Global Modernities, ed. Mike Featherstone, Scott Lash, and Roland Robertson, London: Sage, 45-68.

Nisbet, Robert A. (1973), The Social Philosophers: Community and Conflict in Western Thought, New York: Crowell.

Öncü, Ayşe (1997), “The Myth of the Ideal Home Travels Across Cultural Borders to Istanbul," in Space, Culture, Power: Struggles Over New Identities in Globalizing Cities, ed. Ayşe Oüncuü and Petra Weyland, London: ZED, 56-72.

Özman, Aylin and Simten Coşar (2007), "Re-Conceptualizing Center Politics in Post-1980 Turkey: Transformation or Continuity?" in Remaking Turkey, ed. Emin F. Keyman, Plymouth, UK: Lexington Books, 201-26.

Parmentier, Marie-Agnès and Eileen Fischer (2015), "Things Fall Apart: The Dynamics of Brand Audience Dissipation," Journal of Consumer Research, 41 (February), 1228-51.

Parsons, Elizabeth (2008), “Thompson's Rubbish Theory: Exploring the Practices of Value Creation," in European Advances in Consumer Research, Vol. 8, ed. Stefania Borghini, Mary A. McGrath, and Cele Otnes, Duluth, MN: Association for Consumer Research, 390-93.

Price, Linda L., Eric J. Arnould, and Carolyn F. Curasi (2000), "Older Consumers' Disposition of Valued Possessions," Journal of Consumer Research, 27 (September), 179-201.

Riessman, Catherine K. (1993), Narrative Analysis, Newbury Park, CA: Sage.

Robins, Kevin (1996), "Interrupting Identities: Turkey/Europe," in Questions of Cultural Identity, ed. Stuart Hall and Paul du Gay, London: Sage, 61-86.

Rose, Randall L. and Stacy L. Wood (2005), "Paradox and the Consumption of Authenticity Through Reality Television," Journal of Consumer Research, 32 (September), 284-96. 
Sandıkçı, Özlem and Güliz Ger (2010), "Veiling in Style: How Does a Stigmatized Practice Become Fashionable?" Journal of Consumer Research, 37 (June), 15-36.

Sandıkçı, Özlem and Ece Ilhan (2004), "Dowry: A Cherished Possession or an Old-Fashioned Tradition in a Modernizing Society?" in Contemporary Consumption Rituals: A Research Anthology, ed. Cele C. Otnes and Tina M. Lowrey, London: Erlbaum, 149-78.

Sargın, Güven A. (2004), "Displaced Memories, or the Architecture of Forgetting and Remembrance," Environment and Planning D: Society and Space, 22 (5), 659-80.

Schatzki, Theodore (1996), Social Practices: A Wittgensteinian Approach to Human Activity and the Social, New York: Cambridge: Cambridge University Press.

- (2002), The Site of the Social: A Philosophical Account of the Constitution of Social Life and Change, University Park: Pennsylvania State University Press.

Schau, Hope Jensen, Mary C. Gilly, and Mary Wolfinbarger (2009), "Consumer Identity Renaissance: The Resurgence of Identity-Inspired Consumption in Retirement," Journal of Consumer Research, 36 (August), 255-76.

Sennett, Richard (2008), The Craftsman, London: Yale University Press.

Shove, Elizabeth and Mika Pantzar (2005), "Fossilisation," Ethnologia Europaea, 35 (1-2), 59-63.

Shove, Elizabeth, Matthew Watson, Martin Hand, and Jack Ingram (2007), The Design of Everyday Life, Oxford, UK: Berg.
Stone, Elizabeth (1988), Black Sheep and Kissing Cousins: How Our Family Stories Shape Us, New York: Times Books.

Sutton, David (2009), "The Mindful Kitchen, The Embodied Cook: Tools, Technology and Knowledge Transmission on a Greek Island," Material Culture Review/Revue de la Culture Matérielle, 70 (Fall), 63-68.

Thompson, Craig J. (1997), "Interpreting Consumers: A Hermeneutical Framework for Deriving Marketing Insights from the Texts of Consumers' Consumption Stories," Journal of Consumer Research, 34 (November), 438-55.

Thompson, Michael (1979), Rubbish Theory: The Creation and Destruction of Value, Oxford, UK: Oxford University Press.

Tobin, Sheldon S. (1996), "Cherished Possessions: The Meaning of Things," Generations: Journal of the American Society on Aging, 20 (Fall), 46-48.

Tuan, Yi-Fu (1980), "The Significance of the Artifact," Geographical Review, 70 (October), 462-72.

Watson, Matthew and Elizabeth Shove (2008), "Product, Competence, Project and Practice: DIY and the Dynamics of Craft Consumption," Journal of Consumer Culture, 8 (March), 69-89.

Weiner, Annette B. (1985), "Inalienable Wealth," American Ethnologist, 12 (May), 210-27.

- (1992), Inalienable Possessions: The Paradox of Keeping-While-Giving, Berkeley: University of California Press.

Williams, Raymond (1973), The Country and the City, New York: Oxford University Press. 
Copyright of Journal of Consumer Research is the property of Oxford University Press / USA and its content may not be copied or emailed to multiple sites or posted to a listserv without the copyright holder's express written permission. However, users may print, download, or email articles for individual use. 